2017-01-20

From a systematic literature review to integrated definition for sustainable supply chain innovation (SSCI)

Gao, D

http://hdl.handle.net/10026.1/13208

10.1016/j.jclepro.2016.11.153

Journal of Cleaner Production

Elsevier

All content in PEARL is protected by copyright law. Author manuscripts are made available in accordance with publisher policies. Please cite only the published version using the details provided on the item record or document. In the absence of an open licence (e.g. Creative Commons), permissions for further reuse of content should be sought from the publisher or author. 


\section{Accepted Manuscript}

From a systematic literature review to integrated definition for sustainable supply chain innovation (SSCl)

De Gao, Zhiduan Xu, Yilong Z. Ruan, Haiyan Lu

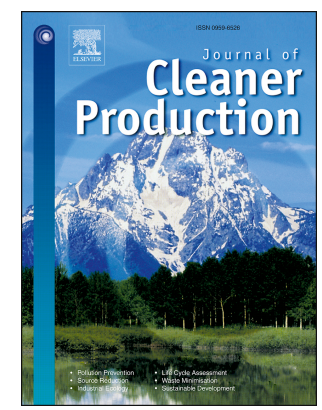

PII:

S0959-6526(16)32015-7

DOI:

10.1016/j.jclepro.2016.11.153

Reference: JCLP 8542

To appear in: Journal of Cleaner Production

Received Date: 17 April 2015

Revised Date: 18 March 2016

Accepted Date: 24 November 2016

Please cite this article as: Gao D, Xu Z, Ruan YZ, Lu H, From a systematic literature review to integrated definition for sustainable supply chain innovation (SSCI), Journal of Cleaner Production (2016), doi: 10.1016/j.jclepro.2016.11.153.

This is a PDF file of an unedited manuscript that has been accepted for publication. As a service to our customers we are providing this early version of the manuscript. The manuscript will undergo copyediting, typesetting, and review of the resulting proof before it is published in its final form. Please note that during the production process errors may be discovered which could affect the content, and all legal disclaimers that apply to the journal pertain. 


\title{
From a systematic literature review to integrated definition for Sustainable Supply Chain Innovation (SSCI)
}

\author{
De Gao ${ }^{a}$, Zhiduan Xu', Yilong Z Ruan ${ }^{a}$, Haiyan $\mathrm{Lu}^{\mathrm{b}}$ \\ ${ }^{\text {a}}$ School of Management, Xiamen University; \\ ${ }^{\mathrm{b}}$ Business School, Cardiff University
}

\begin{abstract}
:
The vast majority of supply-chain literature has focused on supply chain management, innovation and sustainability, separately. However, little supply-chain research focuses on innovation under the supply chain context, which is expected to deliver a sustainable outcome. Is it a great research opportunity to explore or a subject unworthy of studying? This paper offers a systematic literature review considering 107 related papers published from 1996 to 2014. In this review, both descriptive and thematic analyses demonstrate it to be a great research opportunity worthy of exploring. A conceptual framework containing the definition of sustainable supply chain innovation (SSCI) and its distinctive characteristics are proposed and identified. Furthermore, some opportunities for the research in future, such as antecedents to $\mathrm{SSCl}$, are suggested and discussed in this paper. Both academics and practitioners in companies might find this review useful as it stimulates further research and guides sustainable supply chain innovation.
\end{abstract}

Keywords: Innovation; Supply chain management (SCM); Sustainable development; Sustainability; Supply chain innovation (SCI); Sustainable supply chain innovation (SSCI)

\section{Introduction}

Innovation was originally identified by Schumpeter (1934) as the ability to create economic value from new ideas; today, innovation is considered as a key determinant for organizational competitiveness and success (McAdam and Keogh, 2004). Innovation exhibits the direction and progress of the regional and world economic development (Yakovleva et al., 2015). For example, the first handheld mobile cellphone demonstrated by Motorola in 1973 was one of the great innovations in the world (Kempe, 2015). As the essayist Arthur C. Clarke predicted in his book Profiles Of The Future, "We will be able to call a person anywhere on Earth merely by dialing a number and no one need ever again be 
lost." (Clarke, 1964).

Over approximately 40 years of development and popularization, the cellphone has grown from being a luxury item to becoming a daily necessity. According to the data from the International Telecommunications Union (ITU), there were more than seven billion mobile phone subscribers worldwide in 2014, and this number continues to grow (ITU, 2015). A recent survey by Nokia on the Chinese market shows that nearly every respondent has owned more than four cellphones, and other countries such as the U.S., Australia, Brazil and the U.K. have more than one cellphone in use for every citizen (Yufeng, 2012). A research in 2011 showed that Americans replaced their cellphones every 21.7 months (Entner, 2011). Another report in 2014 claimed that approximately 70 percent of users in China replaced their cellphones in 18 months (Qihoo360, 2014). Millions of outdated cellphones are abandoned, few are recycled (Yufeng, 2012). Some studies have argued that this great innovation has generated a severe impact to society and the environment (Inform, 2008). Discarded cellphones are labeled 'electronic waste' or 'e-waste' which may lead to serious health and pollution problems because they may contain contaminants such as lead and cadmium (Sthiannopkao and Ming, 2013). E-waste has become a major challenge to regional and global sustainable development (Selin and VanDeveer, 2006), while its recycling is a "rapidly expanding" issue. To recycle the unwanted cellphones, some innovative activities occurred in the supply chain which may include users, recyclers, logistics, manufacturers and the third-party service platforms. In 2015, Apple China started to join hands with its OEM manufacturer "Foxconn" and the third-party selling and service platform "JD.com" on its "reuse and recycling program". However, the cellphone recycling was not processed as smooth as expected. There are some issues still limiting its expending, like how to protect the users' privacy, how to identify the recycled cellphone to prevent from selling as a new one, and how to price the used cellphone reasonably, etc (Yufeng, 2012).

Observing from case of cellphone, it should be noted that accomplishing a great and sustainable innovation is not only about the product or technology itself, but about its use and disposal in the life cycle. It should not compromise the ability of future generations to meet their own needs while using resources to meet the needs of the present (WCED, 1987), which requests to balance the economic, environmental and social performances (Elkington, 1998). The sustainable innovation should consider all requirements from various stakeholders in the supply chain such as customers, suppliers, regulators, media, non-governmental organization and even competitors. The sustainable innovation is not just created by an enterprise, but also based on the collaborative work and information transfer 
upstream and downstream in the supply chain (Bouncken, 2011), as the transfer of information in the supply chain enriches and channels the activities of design, re-design, and innovation (Christopher, 2007). The sustainable innovation generation considered in a supply chain landscape involves changes in the product, process, or service for the commercial success of the invention (Roy et al., 2004).

The case of cellphone described above shows the intersection of innovation, supply chain management and sustainability. However, upon searching the literature related to sustainable innovation under the supply chain context in the last two decades, we found such research to be rare. Is this a major research opportunity yet unexplored or a subject unworthy of studying? It is an interesting question that a systematic literature review may be able to answer. In practice, the research focusing on the intersection of these three streams may reveal how the innovation in a supply chain can deliver a sustainable outcome. It may be possible to reduce or eliminate 'electronic waste' by recyclable design or design for the environment (Walls and Calcott, 2005).

This paper conducts a systematic literature review aimed at collecting and analyzing relevant papers in the area that overlaps innovation, supply chain management and sustainability. This review starts with innovation practices adopted in supply chain, meanwhile sustainable supply chain is considered as output of innovation practices.

\section{Objectives and Research Methodology}

\subsection{Purpose of research}

A literature review usually aims at two objectives: one is to sum up existing research by identifying the basic characteristics; another is to identify the conceptual content of the research field (Meredith, 1993). The purposes of this review are to:

i. Summarize the literature of innovation research in the supply chain in the last twenty years and analyze it from both descriptive and thematic perspectives;

ii. Explore the linkage among innovation, supply chain and sustainability;

iii. Propose a refined definition of supply chain innovation ( $\mathrm{SCl}$ ) and sustainable supply chain innovation (SSCI), and identify its characteristics;

iv. Highlight the gaps in the current research that need further study.

\subsection{Research methodology}


From the methodological point of view, a literature review can be understood as a content analysis, where quantitative and qualitative aspects are mixed to assess structural (descriptive) as well as content (thematic) criteria (Brewerton and Millward, 2001). This review follows the process model proposed by Mayring (2003) which contains four steps: material collection, descriptive analysis, category selection and material evaluation.

\subsection{Delimitation and search for literature}

The first step in Mayring's process model is to collect articles. The followings describe the process of literature collection:

i. The search was limited to research and review papers published in peer-reviewed journals in English during a twenty-year period between 1995 and 2014, which papers are considered to be formal and rigorous literature;

ii. Databases and online library services such as Elsevier, Web of Science, Emerald, Springer, Wiley and Scopus were selected for this research as they are the ones with the most comprehensive academic resources;

iii. The search started from the fields of title and keyword with the keywords 'innovation', 'supply chain' and 'sustain'. As a result, only eleven related papers were found. To expand the search scope, sustainability was considered as the output of innovation practices in supply chain context so that it was excluded from initial search. The syntax for search in Elsevier is showed below as an example: pub-date > 1994 and pub-date < 2015 and (TITLE(innovation) and TITLE(supply chain)) or (key(innovation) and key(supply chain)) ;

The first paper related to the review topic was published in 1996. All collected papers were first evaluated by a quick scan of the content. Accounting for the stated delimitations, a total of 107 papers about innovation in the supply chain were gathered for detailed review. The software program Endnote was applied to manage these papers. All reviewed papers are listed in Appendix A: Reviewed papers.

\subsection{Rigor of the research process}

The research process and related methodology have natural limitations because of the limitations of resources, time or the researchers' experience and knowledge. To reduce the risk of understanding the literature content based only on the multiple judgments of a single researcher, a principled and structured process was applied to ensure validity. Every paper was reviewed twice with an extensive and intensive review. The inclusion of any disputed 
paper was determined by group discussion and escalated to a senior professor for further review if concern still remained. Targeted information was extracted, induced and coded subsequently.

To exam the research reliability, an intra-rater and inter-rater test was conducted on the four types of papers: review, case study, survey and theoretical papers. The consistencies within one rater and between two raters were $95 \%$ and $79 \%$, respectively, and the related Fleiss kappa values were 0.91 and 0.71 , respectively, which were both higher than 0.7 , the lowest acceptance limit (Fleiss, 1981).

\subsection{Subject of content analysis}

The contents of the collected papers were assessed by methods of descriptive and thematic analyses. The subject of the descriptive analysis in previous literature reviews is used to provide an overview for literature selected, such as the trend of development, the major journals, the most popular methodology applied and the industry sector of focus (Hassini et al., 2012; Klewitz and Hansen, 2014; Linton et al., 2007; Seuring and Müller, 2008). In addition, in the thematic analysis, the analysis is conducted from the innovation phase's perspective and the functional perspective of the sustainable supply chain.

After analyzing the collected literature from the descriptive and thematic perspectives, a refined definition of sustainable supply chain innovation is developed and opportunities for future research are sequentially noted.

\section{Descriptive Analysis}

The second step in Mayring's process model is to conduct a descriptive analysis which provides a descriptive overview on the targeted literature. The following analysis was conducted by published year, published journal, research methodology and industry.

\subsection{Distribution of reviewed papers across the time period}

The basic body of the literature identified comprised 107 papers published from 1995 to 2014. Fig. 1 shows the distribution of all reviewed papers per year across the period studied. The first published paper found was from 1996. It is necessary to note that the development trend of literature can be divided into two stages at the end of the year 2006. According to the product life cycle theory developed by Raymond Vernon, a product's life cycle comprises five stages: introduction, growths, maturity, saturation and decline (Hill, 2007). The first stage before 2006 can be considered an introduction or incubation period of concept 
development which is similar to the introduction stage in a product's life cycle because the volume is flat wavy at a low level. The average number of published papers is no more than 4 per year. Particularly, no papers were published in 1997. The number of published papers rapidly increased after 2006, that year can be regarded as entering the growth stage where the slope of development is much steeper than the previous stage. It can be seen in Fig. 1 that the number of published papers rapidly increased by year. Particularly, the number in 2014 is more than twice the average of the previous years, which are approximately 9 from 2007 to 2013.

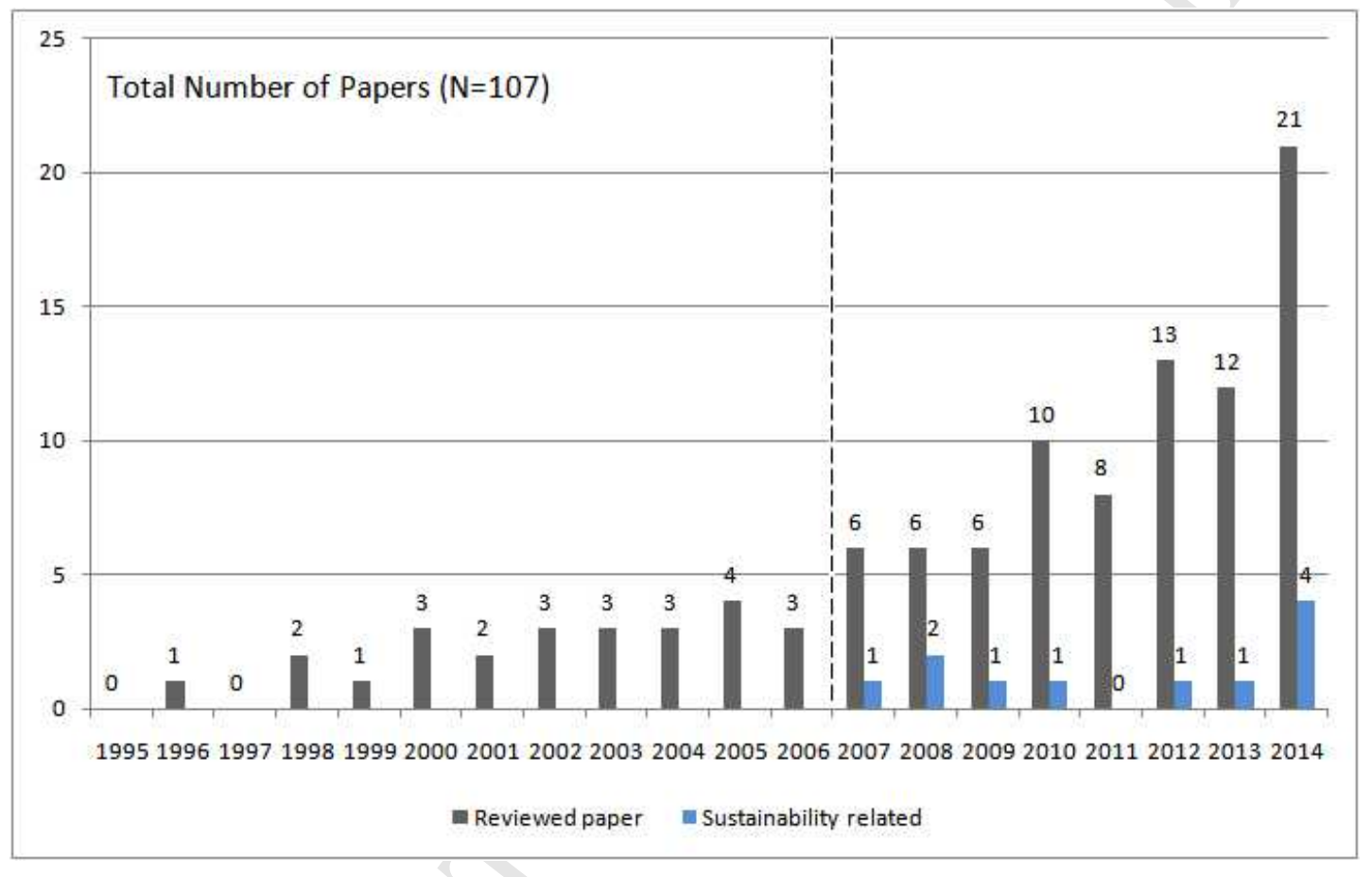

Fig. 1. Distribution of publications per year across the period studied

It is also worth noting that the articles related to sustainable supply chain innovation first occurred in 2007; it appears to currently be at the introduction stage. Assuming its development trend is similar to supply chain innovation, we might be able to predict that the rapid growth stage of the research in sustainable supply chain innovation is approaching soon. The discussion above supports the increasing acceptance of and interest in this topic in this research area.

\subsection{Distribution of reviewed paper by journals}

The reviewed papers are distributed widely across total 68 different journals. Fig. 2 shows that twenty journals have published more than one paper in the collected sample, which account for $63.5 \%$ of the total. By far, the highest ranking journal is the Journal of Operations Management with eight articles, followed by the Journal of Cleaner Production 
with seven articles. Furthermore, greater than one fourth of the total papers (29 in 107 papers) are concentrated in four journals, which play dominant roles in this research field. With regard to articles related to sustainable innovation in the supply chain, the Journal of Cleaner Production ranks first.

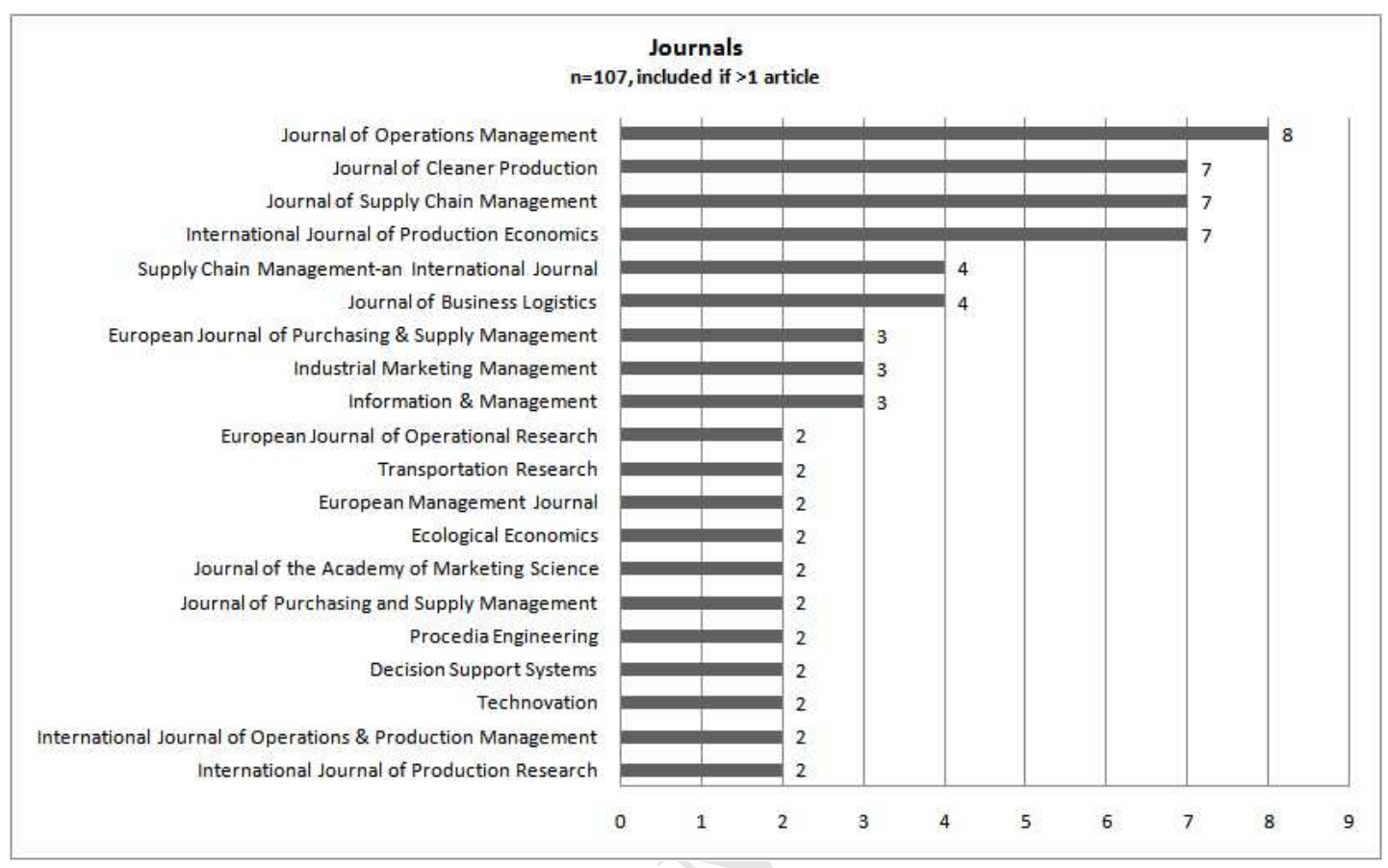

Fig. 2. Distribution of reviewed papers by journal

\subsection{Research methodologies applied}

The methodologies applied in research are usually differentiated into five categories:(1) theoretical and conceptual paper; (2) case study; (3) survey; (4) modeling paper; and (5) literature review (Seuring and Müller, 2008).

Fig. 3 shows the assignment of papers to each research methodology. Survey and case study are the top two most common empirical research methods, comprising three-fourths of the total papers. Furthermore, the case study method is also separated into a single case and multiple cases which cover one-third and two-thirds of case studies, respectively. Theoretical and model development papers rank third and fourth, respectively. It is worth noting that only one literature review was found in this field of study, which summarized the special topic forum on "innovation in business networks from a supply chain perspective: current status and opportunities for future" and introduced four related papers (Arlbjorn and Paulraj, 2013). The lack of systematic review demonstrates the necessity of this study. When focusing only on papers related to sustainable supply chain innovation, case study is the dominant research method (6 of 11 articles). A novel methodology called " $Q$ 
methodology" is observed and grouped as 'other' (Nicholas et al., 2014).

According to the ranking in Fig 3, it can be concluded that the research methodologies favor practical over theoretical approaches. To render the classification transparent to the reader, the research methodology of each paper is listed in Appendix B: Methodologies applied.

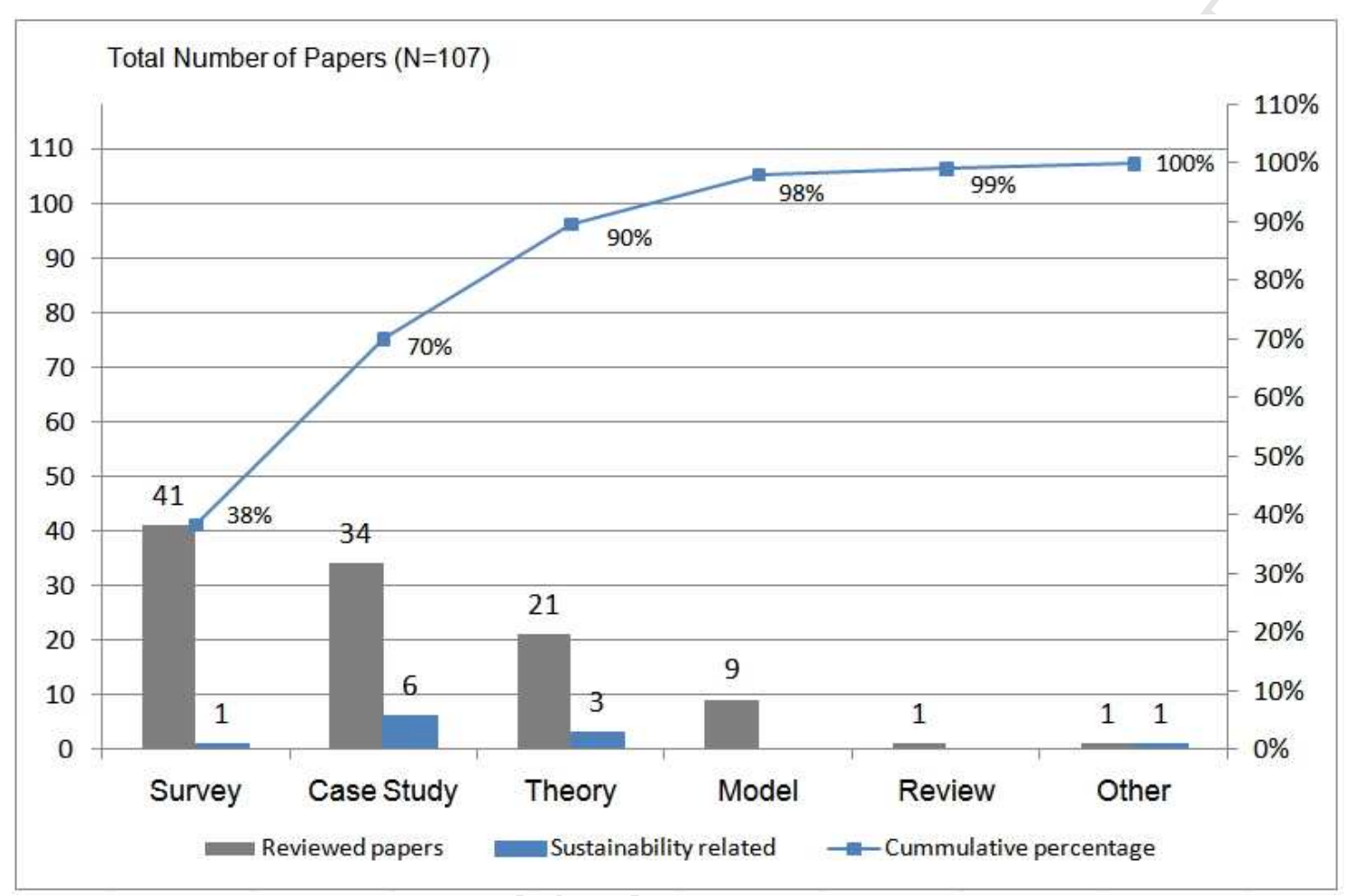

Fig. 3. Research methodologies applied

\subsection{Classification by industry sectors}

The difference between industry sectors is worth investigating because many studies consider industry to be a moderating factor in their frameworks (Flint et al., 2008; Mylan et al., 2014; Wu and Chang, 2012; Wu and Chuang, 2010). However, the industry classification standard is the key for coding. There are two types of popular standards for consideration: GICS and ISIC. GICS (Global Industry Classification Standard) is an industry taxonomy developed by MSCl and S\&P (Standard \& Poor's) and commonly used by the global financial community. Its structure consists of 10 sectors, 24 industry groups, 67 industries and 156 sub-industries (MSCI, 2014). ISIC (International Standard Industrial Classification) is a United Nations system for classifying economic data. It is widely used both nationally and internationally for classifying data according to classifications of economic activity (ISIC, 2008). After the pilot coding, ISIC was selected as the basic classification standard for coding. In addition, two more categories were added as 
supplements, labeled as "V" for "multiple-industries" and "X" for "Unclear or non-mentioned." Thus, the empirical studies using questionnaires to collect survey data from multiple industries were classified with "V," and the theoretical or modeling studies that did not mention any industries of focus were classified with " $X$. ." "S" refers to the service sector covering the five sectors $(\mathrm{N} / \mathrm{S} / \mathrm{R} / \mathrm{O} / \mathrm{P})$ related to service activities in ISIC. Fig. 4a shows the distribution of the industries of focus.

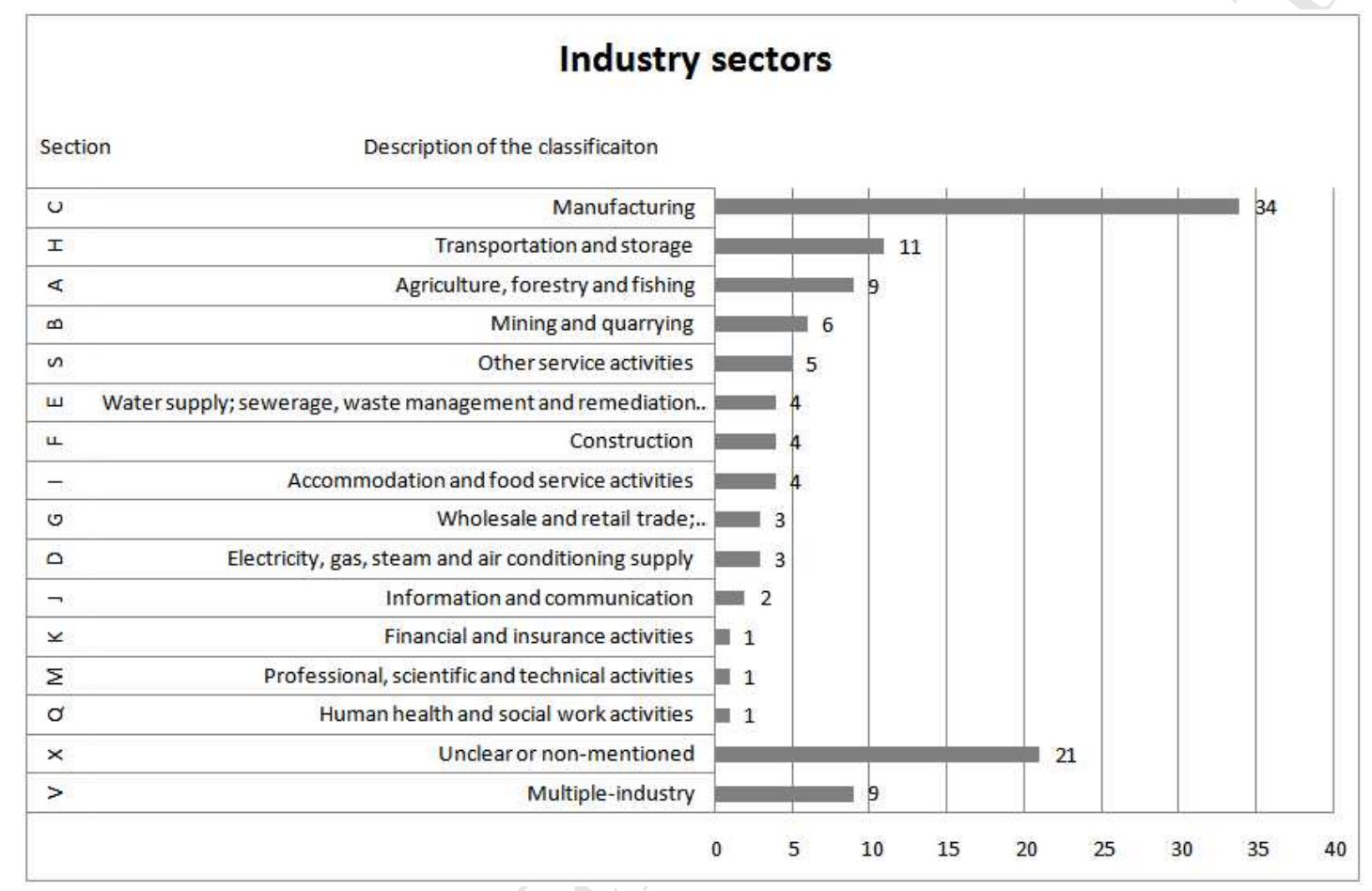

Fig. 4a. Industry sectors in the studies

It can be noted that the manufacturing sector is the most popular sector in research, accounting for approximately $30 \%$ of the total papers. The supply chain innovation focused on 'Manufacturing' can be explained by two reasons. Firstly, it is because of the classification standard. 'Manufacturing' in the classification standard is a major sector comprising 24 divisions, 71 groups, and 189 classes (ISIC, 2008), covering nearly one-fourth of the total industries. Secondly, 'Manufacturing' is a key function creating value in the supply chain, and data are easily collected for research. Another sector 'Transportation and storage' follows 'Manufacturing' as another key function in the supply chain because it makes materials flow. If only the papers related to sustainable supply chain innovation are considered, it is interesting to note that the major sector is not 'Manufacturing' but rather 'Mining' and 'Agriculture'. See Fig. 4b for further details. The reason could be that these two sectors might have a higher probability of releasing pollution to the environment; thus, they have garnered more attention in sustainability research. This view is supported by 
a life cycle assessment case study of oil and gas and agricultural biotechnology (Matos and Hall, 2007).

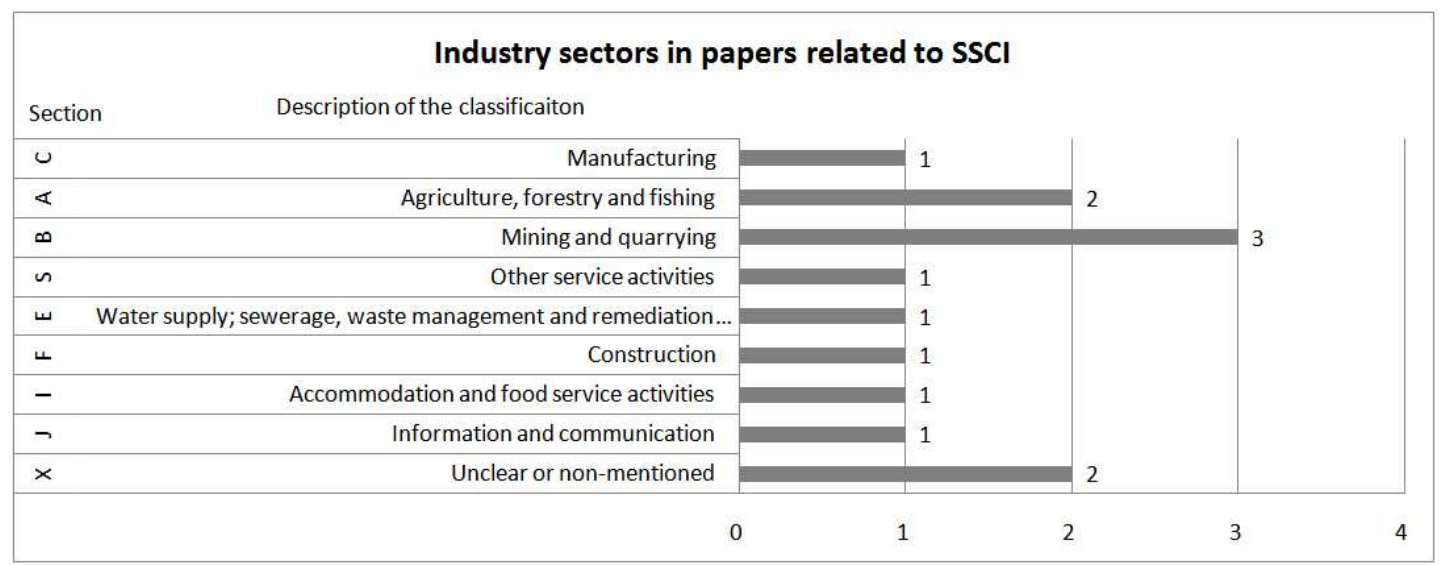

Fig. 4b. Industry sectors in studies related to SSCI

\subsection{Classification by countries of focus}

In this review, we attempt to reveal the difference among countries related to supply chain innovation and the level of sustainability development with different economic levels. Two principles for identifying the "country" characteristics in papers were used: either the information gained directly from papers or the nationality of the first author. The direct information was the first priority if conflicts existed. The evaluation of economic level was based on the gross domestic product (GDP) of each country published by IMF.

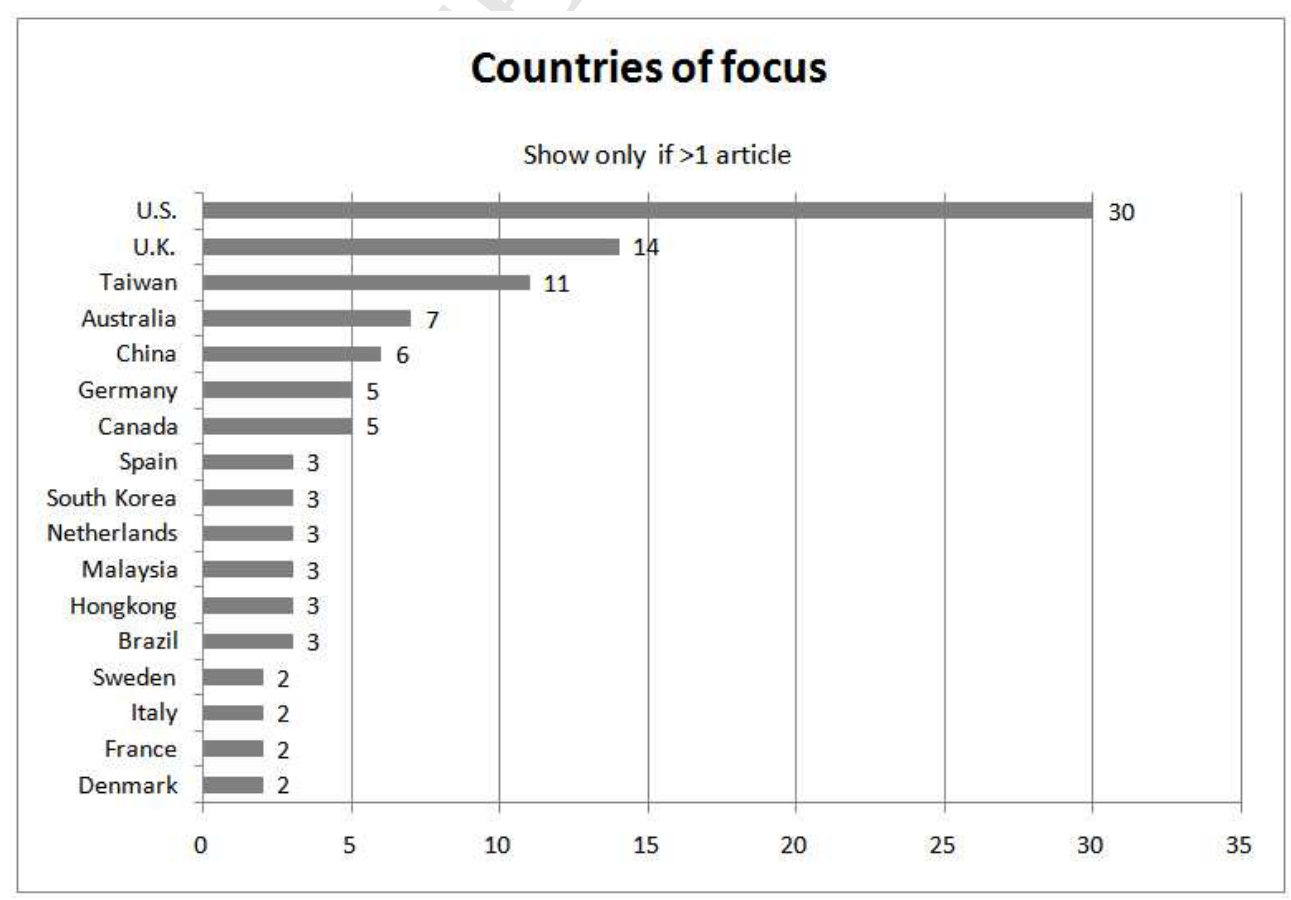

Fig. 5a. Countries of Focus in the studies 


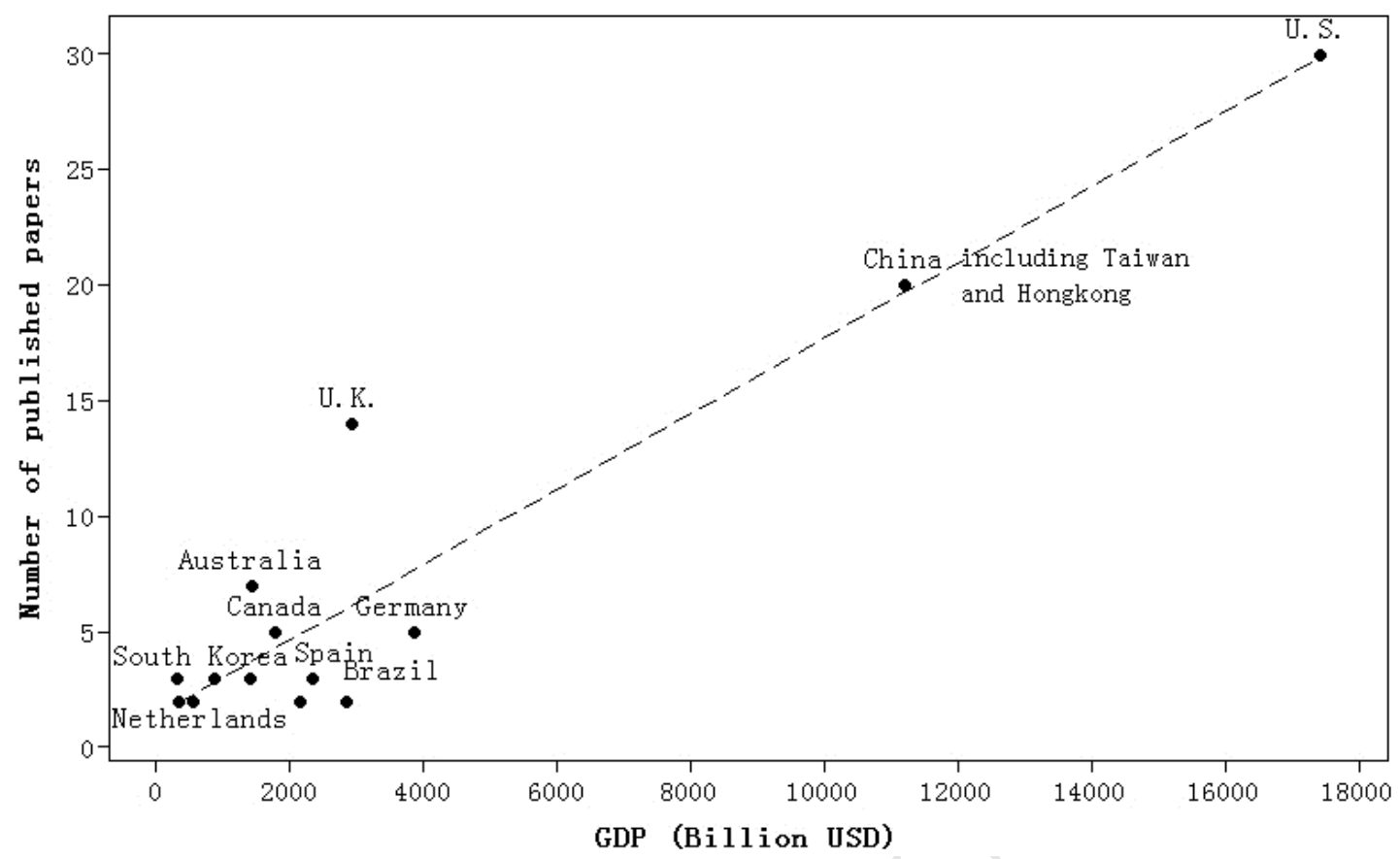

Fig. 5b. GDP vs. Number of published papers

Fig. 5a shows the distribution of countries mentioned in more than one reviewed paper. Ninety-six percent of studies focused on a single country because inter-country research should be difficult to be implemented. Countries with advanced economies such as the U.S. and the U.K. have paid more attention to this topic and account for approximately $40 \%$ of the papers. It is also worth noting that developing economies such as China including Taiwan are both on the top five of the list; in particular, all papers from these two regions were published since 2010, evidencing the increasing focus on this topic in developing countries. Appendix $C$ shows the reviewed papers for each country in detail. Fig. $5 b$ shows the relationship between the GDP of each country and the number of published papers in this research field. The regression dot line on the scatter plot shows the strong relationship between these two variables; the countries with a higher GDP focus more attention on innovation in supply chains as identified by the number of published papers. This conclusion strongly supports the finding in Fig. 5a. However, it should be noted that GDP is not the sufficient factor affecting the number of published papers; for example, Indian GDP ranks ninth in the world in 2014 , but no papers were found related to this research topic.

\section{Thematic Analysis}

According to Mayring's process model, the third step is to identify the categories for literature coding. The thematic analysis below intends to explore the gap of research on 
sustainable supply chain innovation from two perspectives: the innovation process and different functions in a sustainable supply chain. The innovation process in supply chains can be separated into three phases: pre-innovation, innovation and post-innovation. According to Hassini's classification, there are six major relevant functions in sustainable supply chains including sourcing, transformation, delivery, value proposition, customers and product use, and recycling (Hassini et al., 2012). The categories such as the key themes, innovation type, innovation novelty, dimension of sustainability, innovation phases, functions in supply chain and theories applied were selected for coding.

\subsection{Terminology development}

Evaluating the material coded is the last step in Mayring's process model. To demonstrate the terminology development in the reviewed papers and investigate the research opportunities, a set of key definitions related to innovation, supply chain management and sustainability are summarized in Table 1.

From Table 1, the integration and development of concepts can be easily observed. In supply chain innovation, the supply chain enables innovative channel integration, which is defined as "fifth generation innovation" (Rothwell, 1992); it is a multifactor process requiring a high level of integration at both the intra and inter-organizational levels (Liao and Kuo, 2014). The consideration about sustainability improves the expectation of supply chain innovation by effecting an outcome with more than one dimension. However, in the 107 published papers reviewed, there is no clear and complete concept considering all three streams of innovation, supply chain management and sustainability together. A refined and integrated definition for sustainable supply chain innovation is worth developing to close such gap. 
Table 1: Terminology Development

\begin{tabular}{|c|c|c|c|c|}
\hline INN. & SCM & SUS. & Introduction & References \\
\hline \multirow[t]{3}{*}{$x$} & & & $\begin{array}{l}\text { The original concept of innovation was the ability to create economic value from new ideas. With the development } \\
\text { of this concept, researchers defined it with different focuses. From the process perspective, it was defined as the } \\
\text { process of the creation, development, and implementation of new ideas. From the marketing perspective, it was } \\
\text { defined as an iterative process initiated by the perception of a new market and/or new service opportunity for a } \\
\text { technology-based invention which leads to the development, production, and marketing tasks striving for the } \\
\text { commercial success of the invention. From the capability perspective, it was defined as "the capabilities which are } \\
\text { accustomed to developing effective and efficient systems to foresee opportunities, share and re-examine } \\
\text { information using these systems, and overcome organizational inertia." From the cultural and environmental } \\
\text { perspective, it was defined as "the notion of openness to new ideas as an aspect of a firm's culture as measure of } \\
\text { the organization's orientation toward innovation." The central element in these diverse definitions of innovation is a } \\
\text { new idea being put into practice. }\end{array}$ & $\begin{array}{l}\text { (Bouncken, 2011; Damanpour, } \\
\text { 1991; Detre et al., 2011; Garcia } \\
\text { and Calantone, 2002; Gualandris } \\
\text { and Kalchschmidt, 2014; Hult and } \\
\text { Hurley, 1998; Ruff, 2006; } \\
\text { Schumpeter, 1934; Tushman and } \\
\text { Nadler, 1986) }\end{array}$ \\
\hline & $x$ & & $\begin{array}{l}\text { 'Supply chain' refers to "a set of organizations directly linked by one or more of the upstream and downstream flows } \\
\text { of products, services, finances, and information from a source to a customer," and supply chain management } \\
\text { (SCM) was defined by the Global Supply Chain Forum (GSCF) as "...the integration of key business processes } \\
\text { from end users through original suppliers that provide products, services, and information that thus add values for } \\
\text { customers and other stakeholders." }\end{array}$ & $\begin{array}{l}\text { (Lambert et al., 1998; Mentzer et } \\
\text { al., 2001). }\end{array}$ \\
\hline & & $x$ & $\begin{array}{l}\text { Sustainability is generally defined as using resources to meet the needs of the present without compromising the } \\
\text { ability of future generations to meet their own needs. In business, it was defined as the ability to conduct business } \\
\text { with a long-term goal of maintaining the well-being of the economy, environment and society, which was called the } \\
\text { "triple bottom line" by Elkington to emphasize the integration of economic, social, and environmental aspects. }\end{array}$ & $\begin{array}{l}\text { (Elkington, 1998; Hassini et al., } \\
\text { 2012; WCED, 1987) }\end{array}$ \\
\hline
\end{tabular}




\begin{tabular}{|c|c|c|c|c|}
\hline$X$ & $X$ & & $\begin{array}{l}\text { The integration of innovation and supply chain refers to tools that can improve the organizational processes needed } \\
\text { for effective SCM through seamless interactions with suppliers, manufacturers, distributors and customers. Hence, } \\
\text { supply chain innovations result in reductions in cost and lead time, the creation of new operational strategies, the } \\
\text { provision of consistent quality, and the development of flexibility for handling rapid changes in the business } \\
\text { environment. Supply chain innovation management builds on the idea that collaborative work and information } \\
\text { transferred up- and down-stream of the supply chain improve innovation in the supply chain, which enriches the } \\
\text { channels and activities of design, re-design, and innovation. This integration was also extended to the supply chain } \\
\text { network and defined as "an incremental or radical change in process, structure, and/or technology that takes place } \\
\text { in the supply chain network to create value for all stakeholders." Another concept close to supply chain innovation } \\
\text { has been labeled as logistics innovation, indicating any logistics-related service being seen as new and helpful to a } \\
\text { particular focal audience. This audience could be internal to improve operational efficiency or external to better } \\
\text { serve customers. Logistics innovations can range from very basic to very complex. }\end{array}$ & $\begin{array}{l}\text { (Arlbjorn and Paulraj, 2013; } \\
\text { Christopher, 2007; Flint et al., } \\
\text { 2005; Grawe, 2009; Lee et al., } \\
\text { 2011; Lin, 2008) }\end{array}$ \\
\hline & $x$ & $X$ & $\begin{array}{l}\text { The integration of supply chain management and sustainability was advocated as a new archetype for companies } \\
\text { to meet stakeholder requirements and improve profitability and competitiveness while improving ecological } \\
\text { efficiency and social responsibility in their supply chains. Sustainable supply chain management was defined as } \\
\text { "the management of material, information and capital flows as well as cooperation among companies along the } \\
\text { supply chain while taking goals from all three dimensions of sustainable development, i.e., economic, } \\
\text { environmental and social, into account which are derived from customer and stakeholder requirements." }\end{array}$ & $\begin{array}{l}\text { (Ahi and Searcy, 2013; Gualandris } \\
\text { and Kalchschmidt, 2014; Seuring } \\
\text { and Müller, 2008; Zhu et al., 1980) }\end{array}$ \\
\hline$x$ & & $x$ & $\begin{array}{l}\text { In the context of renewable markets, innovation must not only create economic profits but also meet the } \\
\text { environmental and social performance metrics increasingly associated with corporate social responsibility (CSR). A } \\
\text { myriad of terms related to sustainable innovation have been proposed, such as sustainable development } \\
\text { innovation, sustainable innovation, CSR-driven innovation, sustainability-related innovation, sustainability-driven } \\
\text { innovation and sustainability-oriented innovation. }\end{array}$ & $\begin{array}{l}\text { (Amaeshi et al., 2008; Andersson } \\
\text { et al., 2005; Bröring et al., 2006; } \\
\text { Hall, 2002; Hockerts, 2003, 2009; } \\
\text { Klewitz and Hansen, 2014; Little, } \\
\text { 2005; Wagner, 2008) }\end{array}$ \\
\hline
\end{tabular}




\subsection{Key themes in reviewed papers}

The use of coding enables our literature review to identify key themes by the different phases of innovation in the supply chain including pre-innovation, innovation and post-innovation. In pre-innovation, the themes relate to antecedents to innovation including motivators and barriers. Motivators contain some supporting activities such as information sharing, communication and learning (Berghman et al., 2012; Narasimhan, 2013; Wong et al., 2013); requirements from diverse stakeholders such as customers, suppliers and regulators, and secondary stakeholders such as media, non-governmental organization and competitors (Gualandris and Kalchschmidt, 2014; Lau et al., 2014; Mylan et al., 2014; Zhang et al., 2014); and key resources to enable innovation such as technology, relationship and trust (Michalski et al., 2014; Munksgaard et al., 2014; Wagner and Bode, 2014). In addition to resource scarcity, some sources of resistance such as high cost, inertial thinking, complexity and uncertainty highly hinder innovation (Kim and Lim, 2015; Lee et al., 2014; Leung et al., 2014; Nicholas et al., 2014). In innovation, the key themes relate to implementing the innovation. The innovation process can be divided into three, four, or five stages by different researchers. The three-stage process comprises conceptualization and definition, pilot implementation, and full implementation (Holmstrom, 1998). The four-stage process is first formed from a value creation with resource-based view and comprises value co-creation, resources integration and the reconfiguration of value constellation (Lin et al., 2010). The five-stage process comprises initiating or discovering an invention, launching an innovation initiative, embedding the initiative in the organization, focusing the innovation effort, and successfully commercializing the innovation (Narasimhan, 2013). In post-innovation, the key themes relate to innovation adoption and diffusion. Table 2 presents the count of papers identified according to the key themes in different innovation phases. There are some significant differences existing among these three phases. Fewer papers and lower publishing frequency distinguish the innovation phase from the pre- and post-innovation phases. The innovation process may be another opportunity for further research.

Table 2: Key themes with innovation phases

\begin{tabular}{|l|l|c|c|c|}
\hline \multicolumn{1}{|c|}{ Phase } & \multicolumn{1}{|c|}{ Category } & $\begin{array}{c}\text { Count of } \\
\text { paper }\end{array}$ & $\begin{array}{c}\text { Year of the 1st } \\
\text { paper published }\end{array}$ & $\begin{array}{c}\text { Maximum number } \\
\text { of paper published } \\
\text { per year }\end{array}$ \\
\hline Pre-innovation & Antecedent to innovation & 51 & 1996 & 10 \\
\hline Innovation & Innovation process & 12 & 2000 & 3 \\
\hline Post-innovation & Innovation adoption and diffusion & 43 & 1998 & 8 \\
\hline
\end{tabular}


According to the six major relevant functions in sustainable supply chains classified by Hassini et al. (2012), the innovation adoption activities were grouped into six functions. Fig. 6 shows the count of papers in different sustainable supply chain functions. The transformation function also named as "manufacturing" had the highest number of papers. This critical function in a sustainable supply chain has received much research attention, and this conclusion is similar to the finding in 3.4. One key adoption of innovation is to integrate advanced IT technologies or systems into the transformation function. For example, e-SCM implementation enabled the success in SCM practice (Wu and Chuang, 2010), and technology innovations surrounding supply chain communication systems enhance channel relationships and affect market performance (Kim et al., 2006). Another key innovation practice in supply chains is green innovation, such as the diffusion of lead-free soldering in ICT manufacturers (Tong et al., 2012).

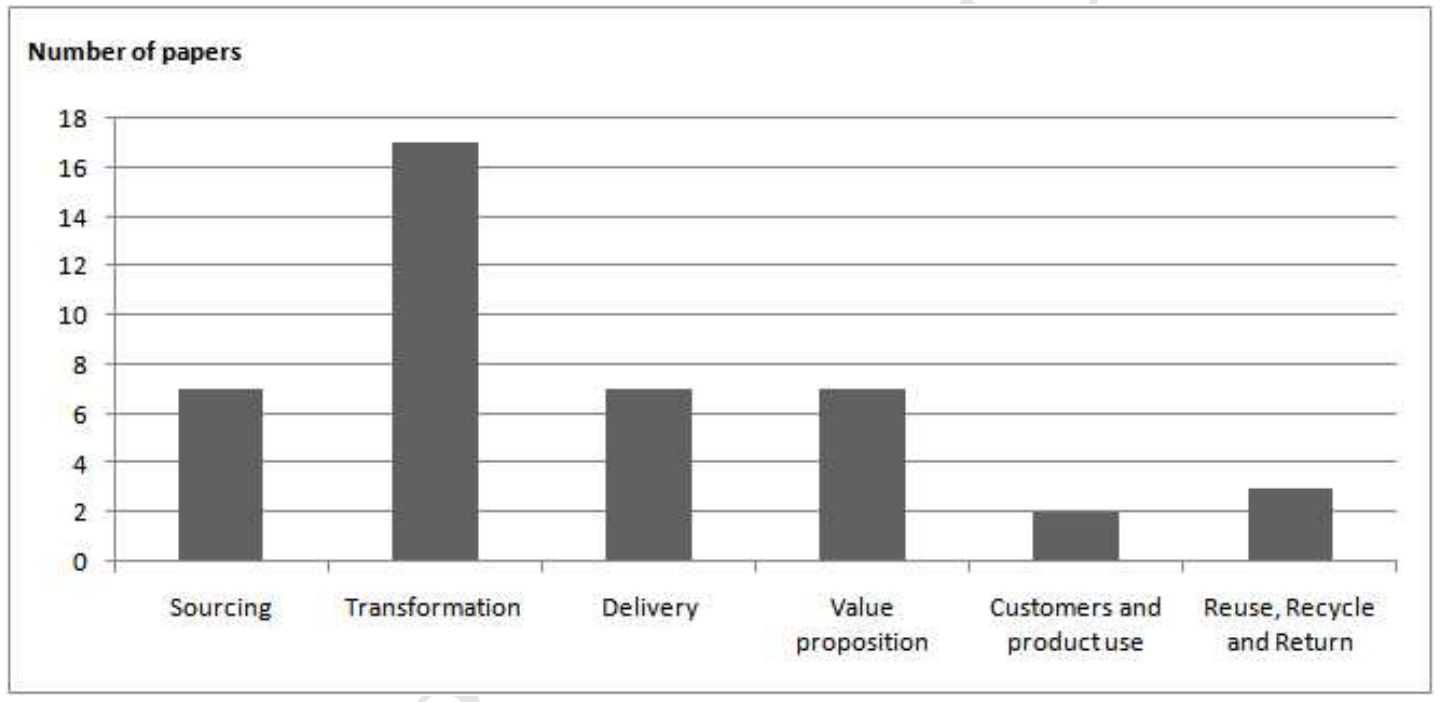

Fig. 6. Count of papers in function of the sustainable supply chain

\subsection{Classification by innovation type}

There are many analytical perspectives for classifying the Innovation types. Schumpeter first argued that innovation undergoes new combinations made by an entrepreneur, resulting in a new product, a new process, the opening of new markets, a new way of organizing the business, and a new source of supply in his book "The Theory of Economic Development" (Schumpeter, 1934). The Organization for Economic Co-operation and Development (OECD) classified the innovation as the implementation of a new or significantly improved product (e.g., change in product properties), process (e.g., changed delivery methods), marketing method (e.g., new product packaging) or organizational method (e.g., changes in workplace organization) in business practices, 
workplace organization, or external relations (OECD, 2000). Based on the organizational ambidexterity developed, scholars have focused on explorative and exploitative innovations (Blome et al., 2013). According to drivers of innovation, innovation has been distinguished into 'technology push' innovation driven by technological discovery and 'market pull' innovation developed in response to market demand (Bruce and Moger, 1999). According to different levels of novelty, researchers have noted the difference between 'radical innovation' such as major processes or product advances, and 'incremental innovation' characterized by the improvement of existing systems (Bessant, 1992). From the innovation approach perspective, innovation can be grouped into technological innovation and administrative innovation for supply chain management (Kim et al., 2006). From the relationship perspective, innovation can also be distinguished into independent innovation and collaborative innovation (Ribeiro, 2009; Zhang et al., 2014). From the result orientation perspective, innovations can be grouped into cost reduction, technological advantage, green or ecological, sustainability-oriented innovations.

In this review, innovation classification follows what Schumpeter proposed originally. Furthermore, technological innovation is considered an additional type. Technology was defined as the "design for instrumental action that reduces the uncertainty in the cause-effect relationships involved in achieving a desired outcome" (Rogers, 1962). As such, nearly any contemporary idea, practice or product that an organization wishes to adopt and employ for the purpose of obtaining gains in performance can be considered as a technological innovation (Hazen et al., 2012). Although technological innovation overlaps with some product and process innovations, many papers applied the term "technological innovation" directly in research.

Table 3a: Innovation types with innovation phases

\begin{tabular}{|l|c|ccc|}
\hline \multirow{2}{*}{ Innovation types } & \multirow{2}{*}{ No. } & \multicolumn{3}{|c|}{ Innovation Phases } \\
\cline { 3 - 5 } & & Pre-Inn. & Inn. & Post-inn. \\
\hline Product Innovation & 32 & $\mathbf{1 4}$ & $\mathbf{5}$ & $\mathbf{1 3}$ \\
\hline Process Innovation & 40 & 21 & 5 & 14 \\
\hline Technological Innovation & 30 & 12 & 2 & 16 \\
\hline Organizational Innovation & 15 & 9 & 3 & 3 \\
\hline Marketing Innovation & 3 & 2 & 1 & - \\
\hline Resource Allocation Innovation & 4 & 1 & 1 & 2 \\
\hline
\end{tabular}

Table 3a shows the innovation types in three phases. It should be noted that most supply chain innovations are related to process, product, technological and organizational innovation. The reason may be because the collaborative activities in the supply chain 
enhance or create new functions of the products and improve the process efficiency and effectiveness. The organizational changes are usually because of the adoption of technological changes or marketing changes. In comparison with other two phases, the innovation phase is still lack of focus in research. It may be interesting to note that the number of organizational innovations in post-innovation phase is much less than the one in pre-innovation phase. The reason could be that adopting organizational innovation by other participants is more difficult than other innovation types in the supply chain.

To explore the relationship between innovation types and functions in a sustainable supply chain, Table 3b shows innovation types with functions in sustainable supply chain; the figure in brackets denotes the number of papers, and the figure outside the brackets represents the item number of typical examples.

Table 3b: Innovation types with functions in sustainable supply chain

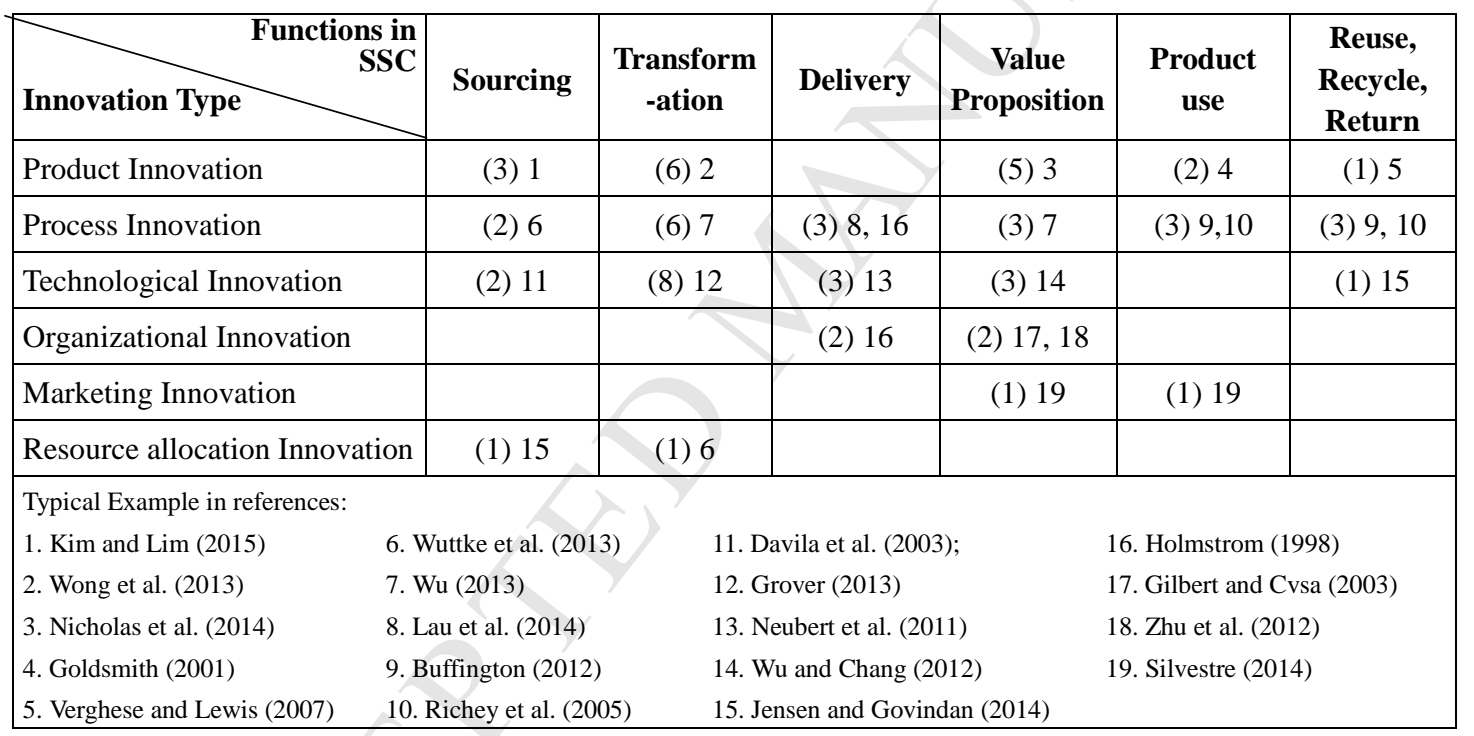

It is easy to find that product innovation occurring in almost all functions of sustainable supply chains except delivery because it is a key function for the focal company to integrate all resources from internal and external supply chains (Wong et al., 2013). For example, the focal company may invite suppliers for joint innovation or even outsource the R\&D in an innovation-driven supply chain (Kim and Lim, 2015). When innovation is successfully developed by the focal company, it should be widely advertised to gain end-user acceptance and adoption; however, acceptance is a long process (e.g., the generalization of genetically modified food) (Nicholas et al., 2014). From the innovator's point of view, the innovations might command a price premium in the marketplace; however, from the adopters' point of view, they face a large investment and a great risk of giving up the original product (Goldsmith, 2001). To reduce the potential 
environmental impact of a product, environmental innovation can be used in product design; for example, the reduction of industrial packaging reduces the supply chain cost and the environmental impacts, making the product more sustainable (Verghese and Lewis, 2007).

Process innovations occur in all functions of the sustainable supply chain, e.g., the innovation of supply chain finance between suppliers and buyer, the employment of green supply chain integration with intra- and inter-organizational environmental practices, the lateral transshipment during product delivery in the supply chain, and development of effective reverse logistics processes to enable aluminum can recycling (Buffington, 2012; Lau et al., 2014; Richey et al., 2005; Wu, 2013; Wuttke et al., 2013). Technological innovation occurs on almost all functions in a supply chain except the customer use. Customer requirement drives technological innovation; however, the innovations require the innovator to master the most advanced technology, which might be hard for general end-users (Gualandris and Kalchschmidt, 2014). In technological innovation, the most common innovation relates to the application of information technology, such as the application of e-procurement, e-SCM and RFID, and to the technology of pollution reduction, such as controlling GHGs and renewable bioenergy applications (Davila et al., 2003; Grover, 2013; Jensen and Govindan, 2014; Neubert et al., 2011; Wu and Chang, 2012).

Comparing the innovations in products, processes and technologies, the innovations in organization, marketing and resource allocation appear to be only related to certain function in a sustainable supply chain. To gain the first mover advantage, the focal company must lead the strategically organizational innovation with partners in the supply chain, and outsourcing and implementing vendor managed inventory are both common adoptions in practice (Gilbert and Cvsa, 2003; Holmstrom, 1998; Zhu et al., 2012). Because innovation is central to sustainable supply chain management (Silvestre, 2014), a new and green market niche might develop or innovations could be applied to emerging economies even with uncertainties (Saint Jean, 2008; Silvestre, 2014). Resource allocation innovation only occurs in the sourcing and transformation functions which demand resource inputs, such as capital, material, energy (Holmstrom, 1998; Wuttke et al., 2013).

\subsection{Classification by innovation novelty}

In supply chain, the interactions of partners such as the buyer-seller interaction generate both incremental and radical innovations (Roy et al., 2004). To distinguish 
between two innovations, innovations were conceptualized as a sequence of $S$ curves, with each $S$ curve representing a distinct type of base technology with its own stream of incremental innovations (Roy et al., 2004). Incremental innovations are considered to move along the same $S$ curve; in contrast, radical innovations are considered as moving from one S curve to another (Asthana, 1995). To investigate the novelty of innovation in supply chains, the innovations in reviewed papers are categorized as radical and incremental.

Table 4: Innovation novelty with innovation phase

\begin{tabular}{|l|c|ccc|}
\hline \multirow{2}{*}{ Degree of Novelty } & \multirow{2}{*}{ Total Number } & \multicolumn{3}{|c|}{ Innovation Phases } \\
\cline { 3 - 5 } & & Pre-Inn. & Inn. & Post-inn. \\
\hline Incremental & 23 & 10 & 4 & 9 \\
\hline Radical & 40 & 11 & 6 & 23 \\
\hline
\end{tabular}

Table 4 shows that radical innovations occur much more often than incremental innovations in the supply chain, particularly in post-innovation phase. Innovations in the supply chain involve changes in product, process, or service that either reduce cost or improve efficiency; the notion of efficiency includes increasing end-of-chain customer satisfaction. A particular S curve involves close teamwork with the concerned suppliers based on interactions and a set of moderating factors. Such close teamwork which involves relationships in which both the strength of the relationship and a high degree of shared knowledge allow very specific technical development work to be undertaken. Jumping across $S$ curves, which involves new knowledge domains, and increases the possibility of radical innovation being generated. More rapid movements across $S$ curves are designated as "increased generation of radical innovations." (Roy et al., 2004). Hence, the innovations in the supply chain comprising many inter-organizational activities are more radical than incremental. The success of radical innovations is more obvious and attractive than incremental to other participants in the supply chain. It encourages them to adopt the best practices.

\subsection{Classification by dimension of sustainability}

The performance of supply chain innovation can be measured through three aspects of sustainability (Sus) including economic (Eco), environmental (Env) and social (Soc) aspects (Labuschagne et al., 2005; Parris and Kates, 2003). To investigate the balance of innovation performance among these three aspects, Table $5 \mathrm{a}$ shows the result of differentiation.

Nearly all supply chain innovations account for economic performance at the 
beginning but not environmental and social performance. Since 2000, environmental and social issues have been considered in supply chain innovations, which can be explained by the increasing demands from a variety of stakeholders, particularly customers and regulators (Gualandris and Kalchschmidt, 2014). A small percentage of innovation has started to consider sustainability since 2007 . This observation is similar to the conclusion drawn in prior research (Seuring and Müller, 2008). The social dimension gains the lowest focus in these three dimensions, which may be because the papers arguing for the social dimension commonly have already considered all three dimensions for sustainability. From the innovation phase perspective, it should be noted that there is no paper studying the innovation process aiming at environmental or social innovation. The possible reason might be the difficulty of distinguishing the difference among these three dimensions.

Table 5a: Dimensions of sustainability with innovation phases

\begin{tabular}{|l|c|c|c|ccc|}
\hline \multirow{2}{*}{ Dimensions } & \multirow{2}{*}{$\begin{array}{c}\text { Number } \\
\text { of papers }\end{array}$} & Percentage & \multirow{2}{*}{$\begin{array}{c}\text { Year of the 1st } \\
\text { paper published }\end{array}$} & \multicolumn{3}{|c|}{ Innovation Phases } \\
\cline { 5 - 7 } & 72 & $67 \%$ & 1996 & 38 & 9 & 24 \\
\hline Eco & 16 & $15 \%$ & 2000 & 5 & - & 11 \\
\hline Eco + Env & 3 & $3 \%$ & 2000 & 2 & - & 1 \\
\hline Eco + Soc & 10 & $9 \%$ & 2007 & 3 & 2 & 5 \\
\hline Sus & & & & & \\
\hline
\end{tabular}

Table $5 \mathrm{~b}$ shows three dimensions of sustainability with functions in sustainable supply chain. It should be noted that there are three characteristics in their relationship. Firstly, no paper specially argues the economic performance at the function of "product use" in the supply chain. An innovation creating economic benefit for customers is the essential and common sense for academics and practitioners, which is the possible reason why it is not worthy of further study. Secondly, at the function of "delivery", all researches focus on economic performance. Most of innovations at this "delivery" function are technological and process innovations, such as the application of RFID, e-SCM and SAP (Holmstrom, 1998; Leung et al., 2014; Neubert et al., 2011; Tajima, 2007; Wu and Chuang, 2009). The application of IT systems and new technologies strongly improve the efficiency of supply chain which results in cost reduction and economic performance improvement. Thirdly, Social dimension still gains less focus than other dimensions. Only one paper specially focuses economic and social dimension at the function of "customers and product use" in supply chain. This paper argued the use of genetically modified seed in farming industry that increased the welfare of entire society. However, the increased concentration among suppliers raised a concern about "fairness to farmers" in this revolution, which is an economic and social issue (Goldsmith, 2001). 
Table 5b: Dimensions of sustainability with functions in sustainable supply chain

\begin{tabular}{|c|c|c|c|c|c|c|}
\hline $\mathrm{C}_{\text {Innovation Type }}^{\begin{array}{r}\text { Functions in } \\
\text { SSC }\end{array}}$ & Sourcing & $\begin{array}{c}\text { Transform- } \\
\text { ation }\end{array}$ & Delivery & $\begin{array}{c}\text { Value } \\
\text { Proposition }\end{array}$ & $\begin{array}{c}\text { Product } \\
\text { use }\end{array}$ & $\begin{array}{l}\text { Reuse, } \\
\text { Recycle, } \\
\text { Return }\end{array}$ \\
\hline Eco & 3 & 8 & 9 & 5 & - & 1 \\
\hline Eco + Env & 1 & 6 & - & 2 & 2 & 3 \\
\hline $\mathrm{Eco}+\mathrm{Soc}$ & - & - & - & - & 1 & $c^{-}$ \\
\hline Sus & 2 & 1 & - & 3 & 1 & 1 \\
\hline
\end{tabular}

\subsection{Various theories applied}

A total of 63 various theories or models have been applied in the reviewed papers, and they are shown in Appendix D: Various Theories applied. Table 6 only lists the top ten theories applied. To analyze how these theories have been applied to the sustainable supply chain innovation, the reviewed papers are differentiated into four groups according to sustainability and its three dimensions which are labeled as Sus, Eco, Env and Soc, respectively. The number of the papers for each group is shown in each column. The economic dimension is assumed as the basic dimension being covered by all papers. Hence, the environmental group includes both economic and environmental dimensions, as does the social group.

Table 6: Top ten theories applied in the papers

\begin{tabular}{|c|c|c|c|c|c|c|c|}
\hline \multirow{2}{*}{ Theories } & \multicolumn{4}{|c|}{ Dimensions of sustainability } & \multicolumn{3}{|c|}{ Innovation Phases } \\
\hline & Eco & Eco+Env & $\mathrm{Eco}+\mathrm{Soc}$ & Sus & Pre-Inn. & Inn. & Post-inn. \\
\hline Resource-Based Theory & $23^{*}$ & 4 & & 3 & $13^{\star *}$ & 2 & 2 \\
\hline Transaction Cost Theory & 12 & 1 & 1 & & 9 & 1 & 2 \\
\hline Innovation Diffusion Theory & 7 & 1 & & & & & 6 \\
\hline Organization Theory & 7 & 2 & & 1 & 3 & 1 & 3 \\
\hline Social Theory & 7 & 1 & & & 7 & & \\
\hline Relationship Theory & 6 & & & & 5 & 1 & \\
\hline Network Theory & 5 & & & & 1 & 2 & \\
\hline Stakeholder Theory & 5 & 4 & 1 & 4 & 3 & 1 & 1 \\
\hline Strategic Approach & 5 & & & & 3 & & 1 \\
\hline Systems Theory & 5 & 3 & & 1 & 5 & & \\
\hline
\end{tabular}

* Number of papers applying the theory to different dimensions of sustainability.

** Number of papers applying the theory to different phases of innovation in supply chains.

It is obvious to note from table 6 that resource-based theory is the major theoretical perspective for sustainability and its economic and environmental dimensions. More than 20 percent of papers apply resource-based related theory to analyze the supply chain 
innovation. The resources include not only the capital, which is defined as the accumulation and deployment of resources with the implicit expectation of positive returns (Brewer, 1984) but also human beings and knowledge. Hence, the resource-based theories comprise the resource-based view (RBV) theory, knowledge-based view theory, resource dependency theory, resource exchange concept, resource advantage theory resource and capability theory and natural-resource-based view (NRBV). From the resource-based view (RBV), the basis for the competitive advantage of a firm lies primarily in the application of a bundle of valuable tangible or intangible resources at the firm's disposal (Barney, 1991). For example, flexibility of the information technology infrastructure is regarded as a set of resources to facilitate the innovation performance (Cheng et al., 2014). The resource-based theories explain the firm's ability to deliver a sustainable competitive advantage through innovation with resources managed in such a way that they cannot be replicated by others, which serves as an ideal barrier to entry, thus securing the firm's competitive advantage and market positioning (Tan and Ndubisi, 2014). The transaction cost theory was used by more than 10 percent of papers, and it was developed by Coase who firstly suggested that the determination of whether a transaction would be implemented across a market between two separate firms or within the same firm was determined by a set of costs (Coase, 1937). The transaction cost theory provides some insight into new governance structures such as vertical integration, licensing, contracts and bundling that such firms employ (Goldsmith, 2001). From the transaction cost view, the structure of a firm's supply chain (or governance structure) is determined by the costs associated with the uncertainty, frequency and degree of asset specificity pertaining to each transaction (Burns, 1978). Restructuring the supply chain through channel innovation reduces the transaction cost (Croom, 2001).

It is necessary to note that few theories are applied to the social dimension as this paper has found little research on this dimension. From the sustainability perspective, the stakeholder theory plays a key role. Stakeholder theory is very popularly applied in supply chain and sustainability research. A stakeholder is defined as any group or individual who can affect or is affected by the achievement of an organization's purpose and includes multiple individuals or groups such as financial claimants, non-governmental agencies, employees, customers, communities, universities, media, and governmental officials, among others (Stubbs and Cocklin, 2008). Stakeholders can be classified into primary and secondary stakeholders (Clarkson, 1995). The requirements of primary stakeholders are usually regarded as the customer pressure to motivate firms to begin and sustain the sustainable supply chain management development process (Gualandris and 
Kalchschmidt, 2014).

As shown in table 6, this study also analyzes the theories applied in the reviewed papers from the innovation process perspective. The reviewed papers are differentiated into the categories of pre-innovation, innovation and post-innovation. As we have mentioned in 4.2, the chief themes in the pre-innovation phase relate to the antecedents to innovation. Except innovation diffusion theory (IDT), almost all of the theories on the list are suitable for pre-innovation research if the resource, transaction cost, organizational structure, social capital, relationship among partners in the supply chain, structure and tie of the supply chain network, stakeholder requirements, strategy and system complexity are considered as key antecedents to innovations in supply chain (Autry and Griffis, 2008; Blome et al., 2013; Cheng et al., 2014; Choi and Krause, 2006; Craighead et al., 2009; Gualandris and Kalchschmidt, 2014; Panayides and Lun, 2009; Wagner and Bode, 2014). Resource-based theory is again the key concept; according to this theory, resources such as technology and trust can influence the innovation (Fawcett et al., 2012; Munksgaard et al., 2014).

In the phase of innovation, six theories with low frequency were applied to the innovation process research. Innovation is regarded as internal and external organizational learning interaction and information-sharing process which target the reduction of transaction costs and meet stakeholder requirements (Berghman et al., 2012; Chapman and Corso, 2005; Silvestre, 2014). In the post-innovation phase, diffusion is the key task; thus, innovation diffusion theory (IDT) has a high frequency of application. Diffusion is the "process by which an innovation is communicated through certain channels over time among the members of a social system" (Rogers, 1962). Diffusion research has been conducted from a variety of different disciplines, and its origins can be traced back to Tarde in 1903 (Harrison and Waite, 2006). Rogers' diffusion model is widely accepted; he suggested that the organization could be classified into five categories(innovators, early adopters, early majority, late majority, and laggards) with two stages of diffusion: adoption and implementation (Rogers, 1962). With the effort of prior researchers, the extended stage-based diffusion models varying from two to six stages have been well summarized in Wu's studies (Wu and Chang, 2012; Wu and Chuang, 2009). During innovation adoption and diffusion, the cultural theory systematically addressed the difficulty because of the complexity of different individual perspectives (Matos and Hall, 2007). 


\section{Conceptual Framework for Sustainable Supply Chain Innovation (SSCI)}

\subsection{Sustainable supply chain innovation (SSCI) framework}

The linkage between the innovative firm and its supply chain is even more important when one considers that a sustainable supply chain is one of the few remaining ways for a company to achieve a sustainable competitive advantage (Damanpour, 1991); hence, sustainable innovations need to extend beyond one individual firm to a connected supply chain of firms.

According to the literature reviewed above, the concepts of innovation in supply chains have been developed by researchers to a certain extent. However, the developments contain partial or fractional views when evaluated from the supply chain and sustainable perspectives. For example, most studies have mainly focused on the focal companies and interaction with suppliers (Vale, 2004; Wong et al., 2013; Wuttke et al., 2013). Similarly, some studies have mainly argued the environmental dimension of sustainability known as green innovation or eco-innovation (Chiou et al., 2011; Seman et al., 2012; Wu, 2013; Zhu et al., 2012). It is necessary to note the lack of one clear and complete concept considering the three aspects of innovation, supply chain management and sustainability together which can enable a more accurate understanding of sustainable supply chain innovation. Based on the prior studies, this paper aims to integrate these three research streams and establish complete and accurate definitions for supply chain innovation (SCI) and sustainable supply chain innovation (SSCI).

The innovation occurring in the supply chain is expected to deliver some desirable changes and includes all parties, such as multiple tiers of suppliers, R\&D, producers, logistic providers, retailers, and consumers. According to the sustainable supply chain framework proposed by Hassini et al. (2012), different actors in the supply chain fulfilling different responsible functions may have different views on an innovation depending on how it is perceived to affect their business or themselves. In Fig. 7, we illustrate a framework for the conception of sustainable supply chain innovation. Supply chain innovation ( $\mathrm{SCl}$ ) can be envisaged as a large umbrella which encompasses all of the innovative activities occurring in every function in the supply chain. 


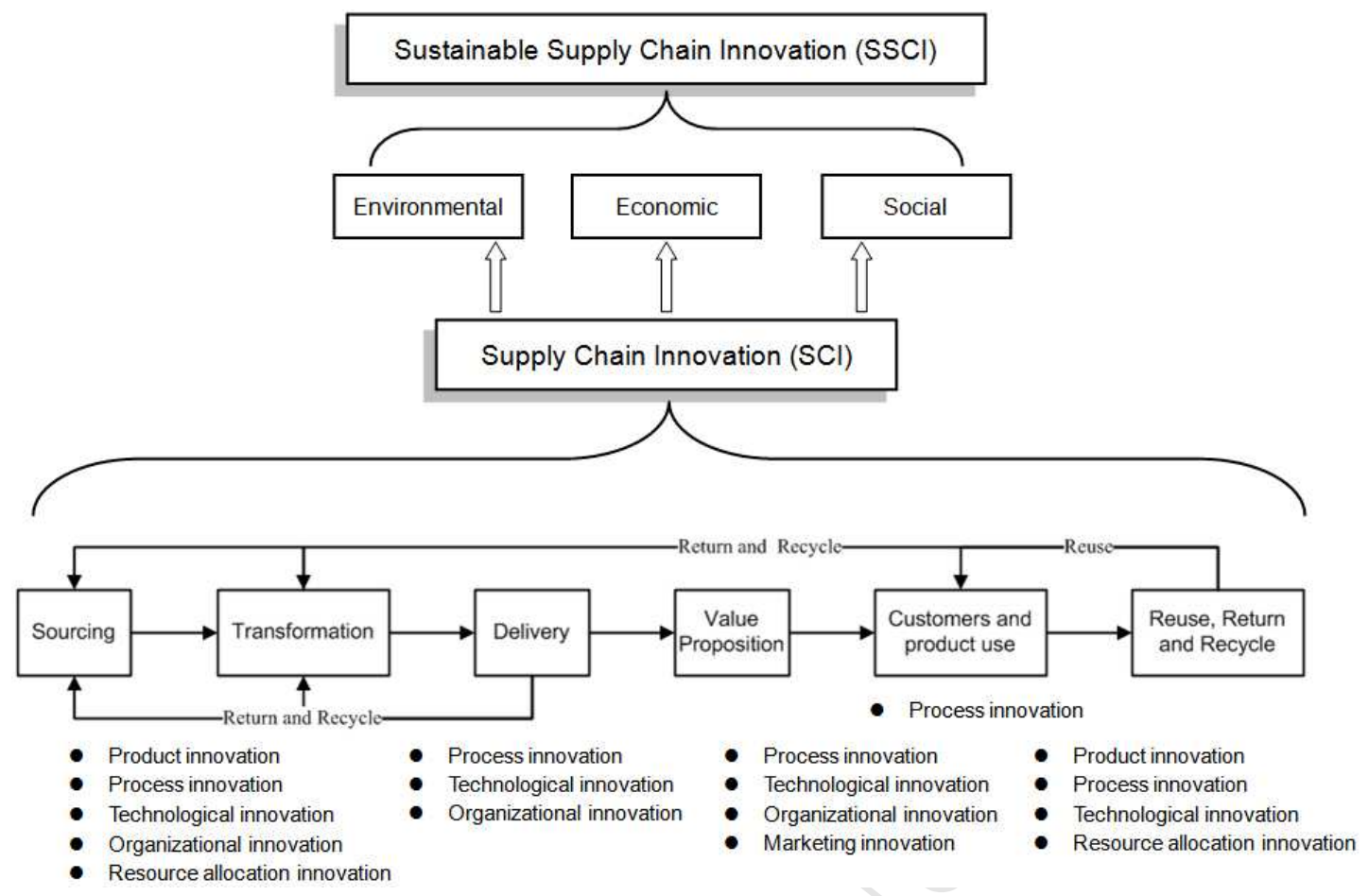

Fig. 7. Sustainable Supply Chain Innovation (SSCI) framework

In such a conceptual framework, supply chain innovation (SCl) comprises a set of innovative activities. In the sourcing and transformation functions, it covers product, process, technological, organizational and resource allocation innovations among multiple tiers of suppliers and producers including R\&D; this innovation may be led by either the supplier or the buyer. The innovation in delivery function, named as logistics innovation by Flint et al. (2005), essentially works as a process, technological or organizational innovation among producers, logistic providers, product sales, customers and/or recyclers. The value proposition function in the supply chain is to quantify the benefits and justify the value added to customers (Hassini et al., 2012), hence, the innovations in value proposition function are sometimes regarded as business model change, service innovation or value innovation (Berghman et al., 2012; Gadde, 2013; Paton and McLaughlin, 2008), and it essentially works as a process, technological, organizational or marketing innovation between product sales and the customers. In the product use function, the customers in the service supply chain may be regarded as component suppliers, labor, design engineers, production managers, products, quality assurance, inventory or even competitors, and it can essentially be regarded as process innovation (Sampson and Spring, 2012). The product reuse, return and recycle functions usually perform as eco-innovation among recyclers, product disposers and/or remanufacturers, and it essential works as a product, process, technological or resource allocation 
innovation (Jabbour et al., 2014; Mylan et al., 2014; Seman et al., 2012). The supply chain innovations could start from accumulating incremental changes to final radical changes or immediately launching a radical change directly. To achieve sustainable innovation, maximizing the supply chain profitability, minimizing the environmental impact and maximizing the social well-being should be considered and balanced at the same time (Elkington, 1998; Hassini et al., 2012). So that it is ready to propose a unified definition for $\mathrm{SCl}$ and $\mathrm{SSCl}$ considering the innovation with different types acceptable to all related parties and covering all related functions in whole supply chain, hence, supply chain innovation ( $\mathrm{SCl}$ ) can be defined as an integrated change from incremental to radical changes in product, process, marketing, technology, resource and/or organization, which are associated with all related parties, covering all related functions in supply chain and creating value for all stakeholders. If the supply chain innovation results in balanced performance of economic, social and environmental dimensions, in other words, all three dimensions have positive innovation performance. It is called a sustainable supply chain innovation (SSCI).

\subsection{Characteristics of SSCI}

The proposed definition of sustainable supply chain innovation (SSCI) which was developed and drawn from prior literature highlights several important characteristics:

(i) Systematic: Sustainable supply chain innovation is a collection of interacting activities that are operated by different participants to achieve a common goal, and it is the typical systematic behavior described in system literature (Elmaghraby, 1966).

(ii) Complex: Complexity is the typical symptom of a system. In supply chain innovation, the complexity can be detected from the product, process, technology, network, and so on. Greater complexity will lead to a lower level of supply chain performance (Closs et al., 2008).

(iii) Internal and external: Sustainable supply chain innovation requires both internal and external activities and capabilities, such as internal learning, absorptive capability, internal integration; external information sharing and coordination (Berghman et al., 2012).

(iv) Dynamic: Facing rapidly changing environments and the changing needs of customers and integrating existing conceptual and empirical knowledge require dynamic capabilities among all parties in a supply chain (Cheng et al., 2014). 
Dynamic capabilities belong to an extension of the resource-based view where supply chain members own different tangible and intangible resources and capabilities ( $\mathrm{Wu}, 2010)$. The processes of change continually produce new externalities that must be addressed (Emerson and Emerson, 1962).

(v) Collaborative: To achieve significant change and conquer the barriers in innovation process such as high-cost pressure, a shortened project cycle and increasing competition, both upstream and downstream parties in supply chain must form a collaborative relationship with each other. Collaboration in the supply chain demands aligned objectives, open communication, sharing of resources, risks and rewards. Collaborative relationships enhance innovation and sustainability performance (Silvestre, 2014).

(vi) Complementary: Each participant in the supply chain has its own advantage and disadvantage. The collaboration enables supply chain participants to create complementary effect in innovation, which is defined as doing more than one activity and increasing the return from doing the other activity (Blome et al., 2013). Complementary can also be named as the "one plus one is greater than two" effect.

(vii) Sustainable: The innovation is associated with all parties in the supply chain; thus, its aim is not only to create value for the focal company but also to consider the needs of all stakeholders. Hence, this type of innovation will search for balance among economic, social and environmental performance, which was called as sustainable performance. A new archetype is for supply chain participants to meet stakeholder requirements and improve profitability and competiveness while improving ecological efficiency and social responsibility (Gualandris and Kalchschmidt, 2014).

(viii) From incremental to radical: supply chain innovation usually accumulates from small changes or further intra-organizational optimization to significant changes in inter-organizational optimization (Tseng et al., 2013).

\subsection{Discussion and suggestions for further research}

This literature review has described and analyzed the prior research on supply chain innovation related to sustainability. The research trend shows that $\mathrm{SSCl}$ has gained increasingly attention. The next central aim of a systematic literature review is to identify the opportunities for future research. Here are some research opportunities captured and 
discussed.

Firstly, an integrated and completed definition for SCI and SSCI has been proposed. This generalized definition contains different types of innovation covering all related functions in the supply chain. In further research, an empirical study such as a case study is necessary to demonstrate the effectiveness of the definitions.

Secondly, as seen in this review, some researchers have argued which antecedents may motive or hinder the innovation. However, most of the studies were under the context of an individual or binary relationship. The antecedents of sustainable innovation under the supply chain context and the mechanism of SSCl are worth investigating, and a survey approach using questionnaires is strongly recommended.

Thirdly, almost all of the studies, the case studies in particular, were conducted by a cross-sectional approach. Cross-sectional studies benefit the comparison analysis, but they lack a longitudinal evolutionary analysis which is important for the incremental innovation research. Particularly, if the innovation is expected to achieve sustainable performance, the environmental impact may not be measured over a short term, and a longitudinal study may be more suitable for revealing the evolution of the sustainable innovation (Lee et al., 2014; Richey et al., 2005; Wagner and Bode, 2014).

Fourthly, as we have mentioned in the previous literature review, few studies have discussed the process of SSCl. How is sustainable innovation generated in the supply chain context? What are the differences in process in different industries or in different business types such as $\mathrm{B} 2 \mathrm{~B}$ and $\mathrm{B} 2 \mathrm{C}$ ? These questions are very interesting for further research.

Fifthly, although a measurement of the sustainability of corporations or supply chains has been proposed in some literature, most measurements focus on environmental dimension such as the reduction of GHG emissions, disposition of waste, reduction in compliance costs, and so forth (Amini and Bienstock, 2014; Hassini et al., 2012; Lang et al., 2007). Isaksson et al. (2010) proposed a process model with some performance indicators to measure the innovation potential; however, the model only focuses on process innovation. It is worth noting that creating an effective system for evaluating the sustainable supply chain innovation is necessary.

Finally, benefit sharing and risk taking are both two key issues which motivate or hinder supply chain innovations; some researchers have proposed that the strategic commitment to price can stimulate downstream innovation in a supply chain (Gilbert and 
Cvsa, 2003). However, the method of sharing the benefits and risks of innovation with all participants in supply chain is still unclear.

This systematic literature review delivers meaningful implications for both academics and practitioners. This study reveals the trend of $\mathrm{SSCl}$, and the definition proposed provides a unified way for communication in the research and practice on sustainable supply chain innovation. Furthermore, for academic research, the characteristics of SSCI are described well in this study to help researchers identify what is true $\mathrm{SSCl}$, and six opportunities are identified to provide directions for further academic research. For practitioners, this study clearly emphasizes the importance of sustainability in supply chain innovation. A long-term strategic view is strongly recommended by this study. All parties in the supply chain are encouraged to seek for the supply chain innovations that consider all three dimensions of sustainability rather than profitability, and sustainable innovation will create and maintain the long-term competition advantage for supply chain.

\section{Conclusions}

In this paper, we have conducted a systematic review of sustainable supply chain innovation. It is necessary to note that the present literature review has existing limitations. Firstly, with our focus on academic journal papers in English, we are aware of excluding papers in other languages as well as other types of publications, such as conference papers which might lead to some loss of knowledge. Secondly, due to the keyword-based searching method applied to the publications, it is possible that some papers related to the research focus but with different keywords were excluded. Finally, the findings in the literature review strongly depend on the reviewers' experience and educational background.

Despite the limitations, this study following Mayring's content analysis model still provides some significant findings to academic research and managerial practice by analyzing interdisciplinary literature from diverse fields as broad as innovation, supply chain management and sustainability.

In the descriptive analysis, the rapidly increasing tendency and the stage breakpoint during the year 2006 were clearly described and summarized. Three key published journals taking a dominant position were identified. Survey and case study were found to be the main research methodologies applied. Manufacturing was found to be the main industry sector in supply chain innovations. 
To explore the linkage among innovation, supply chain management and sustainability, the thematic analysis was conducted by innovation process and sustainable supply chain perspectives. As the result of analysis, the antecedents to innovation and the transformation function were identified as the most important and popular themes in the reviewed literature. Advanced countries have been proven to pay more attention to this topic, and the attention rate is positively related to the economic level. Process, product and technological innovations are regarded as the major innovation types, and different functions in supply chain lead to different types of innovation. In the supply chain, innovation is more radical, and its economic consideration has a much higher priority than the environmental and social dimensions. The application frequency of theories applied in supply chain innovation are summarized and analyzed, and the resource-based theory is ranked as the most popular one.

This study also delivers some significant contributions. The definitions of supply chain innovation ( $\mathrm{SCl}$ ) and sustainable supply chain innovation (SSCl) are proposed by an integrated and completed framework with identified characteristics. Several suggestions are advanced to guide further research. It should be mentioned that a case study on the $\mathrm{SSCl}$ process and the study on antecedents to SSCl are in progress, which will continue to contribute to the research on SSCI.

\section{References:}

Ahi, P., Searcy, C., 2013. A comparative literature analysis of definitions for green and sustainable supply chain management. Journal of Cleaner Production 52, 329-341.

Amaeshi, K.M., Osuji, O.K., Nnodim, P., 2008. Corporate Social Responsibility in Supply Chains of Global Brands: A Boundaryless Responsibility? Clarifications, Exceptions and Implications. J Bus Ethics 81, 223-234.

Amini, M., Bienstock, C.C., 2014. Corporate sustainability: an integrative definition and framework to evaluate corporate practice and guide academic research. Journal of Cleaner Production 76, 12-19.

Andersson, R., Algers, B., Bergström, L., Lundström, K., Nybrant, T., Sjödén, P.-O., 2005. Food 21: A Research Program Looking for Measures and tools to Increase Food Chain Sustainability. AMBIO A Journal of the Human Environment 34, 275-282.

Arlbjorn, J.S., Paulraj, A., 2013. Special Topic Forum on Innovation in Business Networks from a Supply Chain Perspective: Current Status and Opportunities for Future Research. Journal of Supply Chain Management 49, 3-11.

Asthana, P., 1995. Jumping the technology s-curve. Spectrum, IEEE 32, 49 - 54.

Autry, C.W., Griffis, S.E., 2008. Supply Chain Capital: The Impact of Structural and Relational Linkages on Firm Execution and Innovation. Journal of Business Logistics 29, 157-+.

Barney, J.B., 1991. Firm Resources and Sustained Competitive Advantage. Journal of Management.

Berghman, L., Matthyssens, P., Vandenbempt, K., 2012. Value innovation, deliberate learning 
mechanisms and information from supply chain partners. Ind Market Manag 41, 27-39.

Bessant, J., 1992. Big bang or continuous evolution: why incremental innovation is gaining attention in successful organisations. Creativity and innovation management 1, 59-62.

Blome, C., Schoenherr, T., Kaesser, M., 2013. Ambidextrous Governance in Supply Chains: The Impact on Innovation and Cost Performance. Journal of Supply Chain Management 49, 59-80.

Bouncken, R.B., 2011. Supply Chain Contingencies: The Effects of Up-Stream Directives on Supplier's Innovation Performance. Emj-Eng Manag J 23, 36-46.

Bröring, S., Cloutier, L.M., Leker, J., 2006. The Front End of Innovation in an Era of Industry Convergence: Evidence from Nutraceuticals and Functional Foods. Social Science Electronic Publishing 36, 487-498.

Brewer, A., 1984. A Guide to Marx's 'Capital'. Anthony Brewer.

Brewerton, P.M., Millward, L., 2001. Organizational Research Methods, 1st ed. Sege Publication Ltd, London.

Bruce, M., Moger, S.T., 1999. Dangerous liaisons: An application of supply chain modelling for studying innovation within the UK clothing industry. Technol Anal Strateg 11, 113-125.

Buffington, J., 2012. The Beverage Can in the United States: Achieving a 100\% Recycled Aluminum Can through Supply Chain Innovation. Jom-Us 64, 923-932.

Burns, T.J., 1978. Markets and Hierarchies: Analysis and Antitrust Implications. Accounting Review.

Chapman, R.L., Corso, M., 2005. From continuous improvement to collaborative innovation: the next challenge in supply chain management. Prod Plan Control 16, 339-344.

Cheng, J.H., Chen, M.C., Huang, C.M., 2014. Assessing inter-organizational innovation performance through relational governance and dynamic capabilities in supply chains. Supply Chain Manag 19, 173-186.

Chiou, T.Y., Chan, H.K., Lettice, F., Chung, S.H., 2011. The influence of greening the suppliers and green innovation on environmental performance and competitive advantage in Taiwan. Transport Res E-Log 47, 822-836.

Choi, T.Y., Krause, D.R., 2006. The supply base and its complexity: Implications for transaction costs, risks, responsiveness, and innovation. J Oper Manag 24, 637-652.

Christopher, M., 2007. Logistics and Supply Chain Management: Strategies for Reducing Cost and Improving Service (Second Edition). International Journal of Logistics Research and Applications: A Leading Journal of Supply Chain Management 2, 103-104.

Clarke, A.C., 1964. Profiles of the future. Pan Books.

Clarkson, M.E., 1995. A Stakeholder Framework For Analyzing And Evaluating Corporate Social Performance. The Academy of Management Review 20, 92-117.

Closs, D.J., Jacobs, M.A., Swink, M., Webb, G.S., 2008. Toward a theory of competencies for the management of product complexity: Six case studies. J Oper Manag 26, 590-610.

Coase, R.H., 1937. The Nature of the Firm. Social Science Electronic Publishing 4, 386-405.

Craighead, C.W., Hult, G.T.M., Ketchen, D.J., 2009. The effects of innovation-cost strategy, knowledge, and action in the supply chain on firm performance. J Oper Manag 27, 405-421.

Croom, S., 2001. Restructuring supply chains through information channel innovation. Int J Oper Prod Man 21, 504-515.

Damanpour, F., 1991. Organizational Innovation: A Meta-Analysis of Effects of Determinants and Moderators. ACAD MANAGE J 34, 555-590.

Davila, A., Gupta, M., Palmer, R., 2003. Moving Procurement Systems to the Internet. European 
Management Journal 21, 11-23.

Detre, J.D., Johnson, A.J., Gray, A.W., 2011. Innovativeness and Innovation: Implications for the Renewable Materials Supply Chain. Int Food Agribus Man 14, 17-34.

Elkington, J., 1998. Partnerships from cannibals with forks: The triple bottom line of 21st-century business. Environmental Quality Management 8, 37-51.

Elmaghraby, S.E., 1966. The design of production systems. Reinhold Pub. Corp.

Emerson, R.M., Emerson, R.M., 1962. Power-Dependence Relations. AMERICAN SOCIOLOGICAL REVIEW 27, 31-41.

Entner, R., 2011. International Comparisons: The Handset Replacement Cycle.

Fawcett, S.E., Jones, S.L., Fawcett, A.M., 2012. Supply chain trust: The catalyst for collaborative innovation. Bus Horizons 55, 163-178.

Fleiss, J., 1981. The measurement of interrater agreement. Statistical methods for rates and proportions. Statistical Methods for Rates \& Proportions Third Edition.

Flint, D.J., Larsson, E., Gammelgaard, B., 2008. Exploring Processes for Customer Value Insights, Supply Chain Learning and Innovation: An International Study. Journal of Business Logistics 29, 257.

Flint, D.J., Larsson, E., Gammelgaard, B., Mentzer, J.T., 2005. Logistics Innovation: A Customer Value-Oriented Social Process. Journal of Business Logistics 26, 113-147.

Gadde, L.-E., 2013. Moving Corporate Boundaries: Consequences for Innovative Redesign. Journal of Supply Chain Management 49, 12-26.

Garcia, R., Calantone, R., 2002. A critical look at technological innovation typology and innovativeness terminology: a literature review. Journal of Product Innovation Management 19, 110-132.

Gilbert, S.M., Cvsa, V., 2003. Strategic commitment to price to stimulate downstream innovation in a supply chain. Eur J Oper Res 150, 617-639.

Goldsmith, P.D., 2001. Innovation, supply chain control, and the welfare of farmers - The economics of genetically modified seeds. Am Behav Sci 44, 1302-1326.

Grawe, S.J., 2009. Logistics innovation: a literature - based conceptual framework. The International Journal of Logistics Management 20, 360-377.

Grover, D., 2013. The 'advancedness' of knowledge in pollution-saving technological change with a qualitative application to SO2 cap and trade. Ecol Econ 89, 123-134.

Gualandris, J., Kalchschmidt, M., 2014. Customer pressure and innovativeness: Their role in sustainable supply chain management. Journal of Purchasing and Supply Management 20, 92-103.

Hall, J., 2002. Sustainable development innovation; a research agenda for the next 10 yearsEditorial for the 10th Anniversary of the Journal of Cleaner Production. Journal of Cleaner Production 10, 195-196.

Harrison, T., Waite, K., 2006. A time-based assessment of the influences, uses and benefits of intermediary website adoption. Inform Manage-Amster 43, 1002-1013.

Hassini, E., Surti, C., Searcy, C., 2012. A literature review and a case study of sustainable supply chains with a focus on metrics. International Journal of Production Economics 140, 69-82.

Hazen, B.T., Overstreet, R.E., Cegielski, C.G., 2012. Supply chain innovation diffusion: going beyond adoption. Int J Logist Manag 23, 119-134.

Hill, C., 2007. International Business Competing in the Global Marketplace, 6th ed. McGraw-Hill.

Hockerts, K.N., 2003. Sustainability innovations: ecological and social entrepreneurship and the management of antagonistic assets. na. 
Hockerts, K.N., 2009. CSR-driven Innovation e Towards the Social Purpose Business.

Holmstrom, J., 1998. Business process innovation in the supply chain a case study of implementing vendor managed inventory.

Hult, G.T.M., Hurley, R.F., 1998. Innovation, market orientation, and organizational learning: An integration and empirical examination. Journal of marketing: A quarterly publication of the american marketing association 62, págs. 42-54.

Inform, 2008. The Secret Life of Cell Phone.

Isaksson, R., Johansson, P., Fischer, K., 2010. Detecting Supply Chain Innovation Potential for Sustainable Development. J Bus Ethics 97, 425-442.

ISIC, 2008. International Standard Industrial Classification of All Economic Activities, 4th ed. United Nations, New York.

ITU, 2015. Our vision: committed to connecting the world.

Jabbour, C.J.C., Neto, A.S., Gobbo, J.A., Ribeiro, M.d.S., Jabbour, A.B.L.d.S., 2014. "Eco-innovations in more sustainable supply chains for a low-carbon economy: A multiple case study of human critical success factors in Brazilian leading companies". International Journal of Production Economics.

Jensen, J.K., Govindan, K., 2014. Assessment of renewable bioenergy application: a case in the food supply chain industry. Journal of Cleaner Production 66, 254-263.

Kempe, A., 2015. The Mobile - an exhibition of mobile phones. The National Museum of Sience and Technology.

Kim, D., Cavusgil, S.T., Calantone, R.J., 2006. Information system innovations and supply chain management: Channel relationships and firm performance. J Acad Market Sci 34, 40-54.

Kim, K.-K., Lim, M.K., 2015. R\&D outsourcing in an innovation-driven supply chain. Operations Research Letters 43, 20-25.

Klewitz, J., Hansen, E.G., 2014. Sustainability-oriented innovation of SMEs: a systematic review. Journal of Cleaner Production 65, 57-75.

Labuschagne, C., Brent, A.C., Erck, R.P.G.v., 2005. Assessing the sustainability performances of industries. Journal of Cleaner Production 13, 373-385.

Lambert, D.M., Cooper, M.C., Pagh, J.D., 1998. Supply Chain Management: Implementation Issues and Research Opportunities. The International Journal of Logistics Management volume 9, 1-20(20).

Lang, D.J., Scholz, R.W., Binder, C.R., Wiek, A., Stäubli, B., 2007. Sustainability Potential Analysis (SPA) of landfills - a systemic approach: theoretical considerations. Journal of Cleaner Production 15, 1628-1638.

Lau, H.C.W., Ho, G.T.S., Chan, T.M., Tsui, W.T., 2014. An innovation approach for achieving cost optimization in supply chain management. J Intell Fuzzy Syst 26, 173-192.

Lee, S.M., Lee, D., Schniederjans, M.J., 2011. Supply chain innovation and organizational performance in the healthcare industry. Int J Oper Prod Man 31, 1193-1214.

Lee, V.H., Ooi, K.B., Chong, A.Y.L., Seow, C., 2014. Creating technological innovation via green supply chain management: An empirical analysis. Expert Syst Appl 41, 6983-6994.

Leung, J., Cheung, W.M., Chu, S.C., 2014. Aligning RFID applications with supply chain strategies. Inform Manage-Amster 51, 260-269.

Liao, S.H., Kuo, F.I., 2014. The study of relationships between the collaboration for supply chain, supply chain capabilities and firm performance: A case of the Taiwan's TFT-LCD industry. International Journal of Production Economics 156, 295-304. 
Lin, C., 2008. Determinants of the adoption of technological innovations by logistics service providers in China. International Journal of Technology Management \& Sustainable Development volume 7, 19-38(20).

Lin, Y.C., Wang, Y.C., Yu, C.H., 2010. Investigating the drivers of the innovation in channel integration and supply chain performance: A strategy orientated perspective. International Journal of Production Economics 127, 320-332.

Linton, J., Klassen, R., Jayaraman, V., 2007. Sustainable supply chains: An introduction. J Oper Manag 25, 1075-1082.

Little, A.D., 2005. Innovation High Ground Report: How Leading Companies Are Using Sustainability-driven Innovation to Win Tomorrow's customers. ADL, UK.

Matos, S., Hall, J., 2007. Integrating sustainable development in the supply chain: The case of life cycle assessment in oil and gas and agricultural biotechnology. J Oper Manag 25, 1083-1102.

Mayring, P., 2003. Qualitative Content Analysis, 8th ed. Weinheim, Germany: Beltz Verlag

McAdam, R., Keogh, W., 2004. Transitioning towards creativity and innovation measurement in SMEs. Creativity and Innovation Management 13, 126-139.

Mentzer, J.T., DeWitt, W., Keebler, J.S., Min, S., Nix, N.W., Smith, C.D., Zacharia, Z.G., 2001. Defining supply chain management. Journal of Business Logistics 22, 1-25.

Meredith, J., 1993. Theory building through conceptual methods. Int J Oper Prod Man 13, 3-11.

Michalski, M., Yurov, K.M., Botella, J.L.M., 2014. Trust and It Innovation in Asymmetric Environments of the Supply Chain Management Process. J Comput Inform Syst 54, 10-24.

$\mathrm{MSCl}$, 2014. Global Industry Classification Standard.

Munksgaard, K.B., Stentoft, J., Paulraj, A., 2014. Value-based supply chain innovation. Oper Manage Res 7, 50-62.

Mylan, J., Geels, F.W., Gee, S., McMeekin, A., Foster, C., 2014. Eco-innovation and retailers in milk, beef and bread chains: enriching environmental supply chain management with insights from innovation studies. Journal of Cleaner Production.

Narasimhan, R., 2013. Perspectives on Supply Network-Enabled Innovations. Journal of Supply Chain Management 49, 27-42.

Neubert, G., Dominguez, C., Ageron, B., 2011. Inter-organisational alignment to enhance information technology (IT) driven services innovation in a supply chain: the case of radio frequency identification (RFID). Int J Comput Integ M 24, 1058-1073.

Nicholas, P.K., Mandolesi, S., Naspetti, S., Zanoli, R., 2014. Innovations in low input and organic dairy supply chains-What is acceptable in Europe? J Dairy Sci 97, 1157-1167.

OECD, 2000. OECD Small And Medium Enterprise Outlook: 2000 Edition. SourceOECD Employment, $1-220(220)$.

Panayides, P.M., Lun, Y.H.V., 2009. The impact of trust on innovativeness and supply chain performance. International Journal of Production Economics 122, 35-46.

Parris, T.M., Kates, R.W., 2003. Characterizing and measuring sustainable development. ANNUAL REVIEW OF ENVIRONMENT AND RESOURCES 28, 559-586.

Paton, R.A., McLaughlin, S., 2008. Services innovation: Knowledge transfer and the supply chain. European Management Journal 26, 77-83.

Qihoo360, 2014. Recycling Value of Old Phone.

Ribeiro, F.L., 2009. Enhancing Knowledge Management In Construction Firms. Construction Innovation: Information, Process, Management. 
Richey, R.G., Chen, H.Z., Genchev, S.E., Daugherty, P.J., 2005. Developing effective reverse logistics programs. Ind Market Manag 34, 830-840.

Rogers, E.M., 1962. Diffusion of innovations. Diffusion of innovations.

Rothwell, R., 1992. Successful industrial innovation: Critical factors for the 1990s, R\&amp;D Management, pp. 221-240.

Roy, S., Sivakumar, K., Wilkinson, I.F., 2004. Innovation generation in supply chain relationships: A conceptual model and research propositions. J Acad Market Sci 32, 61-79.

Ruff, F., 2006. Corporate foresight: integrating the future business environment into innovation and strategy. Int J Technol Manage volume 34, 278-295(218).

Saint Jean, M., 2008. Polluting emissions standards and clean technology trajectories under competitive selection and supply chain pressure. Journal of Cleaner Production 16, S113-S123.

Sampson, S.E., Spring, M., 2012. Customer Roles in Service Supply Chains and Opportunities for Innovation. Journal of Supply Chain Management 48, 30-50.

Schumpeter, J.A., 1934. The Theory of Economic Development: An Inquiry into Profits, Capital, Credit, Interest, and the Business Cycle. Social Science Electronic Publishing.

Selin, H., VanDeveer, S.D., 2006. Raising Global Standards: Hazardous Substances and E-Waste Management in the European Union. Environment Science \& Policy for Sustainable Development 48, 6-18.

Seman, N.A.A., Zakuan, N., Jusoh, A., Arif, M.S.M., Saman, M.Z.M., 2012. The Relationship of Green Supply Chain Management and Green Innovation Concept. Procedia - Social and Behavioral Sciences 57, 453-457.

Seuring, S., Müller, M., 2008. From a literature review to a conceptual framework for sustainable supply chain management. Journal of Cleaner Production 16, 1699-1710.

Silvestre, B.S., 2014. A hard nut to crack! Implementing supply chain sustainability in an emerging economy. Journal of Cleaner Production.

Sthiannopkao, S., Ming, H.W., 2013. Handling e-waste in developed and developing countries: initiatives, practices, and consequences. Science of the Total Environment 463-464, 1147-1153.

Stubbs, W., Cocklin, C., 2008. Conceptualizing a "Sustainability Business Model". Organization \&amp; Environment 21, 103-127.

Tajima, M., 2007. Strategic value of RFID in supply chain management. Journal of Purchasing and Supply Management 13, 261-273.

Tan, Y.C., Ndubisi, N.O., 2014. Evaluating supply chain relationship quality, organisational resources, technological innovation and enterprise performance in the palm oil processing sector in Asia. J Bus Ind Mark 29, 487-498.

Tong, X., Shi, J., Zhou, Y., 2012. Greening of supply chain in developing countries: Diffusion of lead (Pb)-free soldering in ICT manufacturers in China. Ecol Econ 83, 174-182.

Tseng, M.L., Chiu, S.F., Tan, R.R., Siriban-Manalang, A.B., 2013. Sustainable consumption and production for Asia: sustainability through green design and practice. Journal of Cleaner Production 40, 1-5.

Tushman, M., Nadler, D., 1986. Organizing for Innovation. California Management Review 28, 74-92.

Vale, M., 2004. Innovation and knowledge driven by a focal corporation - The case of the Autoeuropa supply chain. Eur Urban Reg Stud 11, 124-140.

Verghese, K., Lewis, H., 2007. Environmental innovation in industrial packaging: a supply chain approach. Int J Prod Res 45, 4381-4401. 
Wagner, M., 2008. Sustainability-related innovation and sustainability management. Centre for Sustainability Management (CSM) e.V.

Wagner, S.M., Bode, C., 2014. Supplier relationship-specific investments and the role of safeguards for supplier innovation sharing. J Oper Manag 32, 65-78.

Walls, M., Calcott, P., 2005. Waste, Recycling, and Design for Environment. Social Science Electronic Publishing.

WCED, 1987. Our Common Future, World Commission on Environment and Development.

Wong, C.W.Y., Wong, C.Y., Boon-itt, S., 2013. The combined effects of internal and external supply chain integration on product innovation. International Journal of Production Economics 146, 566-574.

Wu, G.C., 2013. The influence of green supply chain integration and environmental uncertainty on green innovation in Taiwan's IT industry. Supply Chain Manag 18, 539-552.

Wu, I.L., Chang, C.H., 2012. Using the balanced scorecard in assessing the performance of e-SCM diffusion: A multi-stage perspective. Decis Support Syst 52, 474-485.

Wu, I.L., Chuang, C.H., 2009. Analyzing contextual antecedents for the stage-based diffusion of electronic supply chain management. Electron Commer R A 8, 302-314.

Wu, I.L., Chuang, C.H., 2010. Examining the diffusion of electronic supply chain management with external antecedents and firm performance: A multi-stage analysis. Decis Support Syst 50, 103-115.

Wu, L.-Y., 2010. Applicability of the resource-based and dynamic-capability views under environmental volatility. Journal of Business Research 63, 27-31.

Wuttke, D.A., Blome, C., Foerstl, K., Henke, M., 2013. Managing the Innovation Adoption of Supply Chain FinanceEmpirical Evidence From Six European Case Studies. Journal of Business Logistics 34, 148-166.

Yakovleva, E.A., Azarova, N.A., Titova, E.V., 2015. Innovation as a Vector of Regional Economic Development and a Necessary Condition for the Progress of the World Economy. Asian Social Science 11.

Yufeng, W., 2012. Hanging up on recycling, Global Times, China.

Zhang, W., Zhang, Q., Wu, G., 2014. Interorganizational Knowledge Division Decision Model Based on Cooperative Innovation of Supply Chain System. Abstr Appl Anal 2014, 1-9.

Zhu, Q., Sarkis, J., Geng, Y., 1980. Green supply chain management in China: pressures, practices and performance. Int J Oper Prod Man 25, 449-468.

Zhu, Q., Sarkis, J., Lai, K.-h., 2012. Green supply chain management innovation diffusion and its relationship to organizational improvement: An ecological modernization perspective. J Eng Technol Manage 29, 168-185. 


\section{Appendix A: Reviewed papers (1-107)}

1. Alfaro JA, Rabade LA. Traceability as a strategic tool to improve inventory management: A case study in the food industry. International Journal of Production Economics. 2009;118(1):104-10.

2. Arlbjorn JS, Paulraj A. Special Topic Forum on Innovation in Business Networks from a Supply Chain Perspective: Current Status and Opportunities for Future Research. Journal of Supply Chain Management. 2013;49(4):3-11.

3. Autry CW, Griffis SE. Supply Chain Capital: The Impact of Structural and Relational Linkages on Firm Execution and Innovation. Journal of Business Logistics. 2008;29(1):157-+.

4. Bello DC, Lohtia R, Sangtani V. An institutional analysis of supply chain innovations in global marketing channels. Ind Market Manag. 2004;33(1):57-64.

5. Berghman L, Matthyssens $P$, Vandenbempt K. Value innovation, deliberate learning mechanisms and information from supply chain partners. Ind Market Manag. 2012;41(1):27-39.

6. Blome C, Schoenherr T, Kaesser M. Ambidextrous Governance in Supply Chains: The Impact on Innovation and Cost Performance. Journal of Supply Chain Management. 2013;49(4):59-80.

7. Bohme T, Deakins E, Pepper M, Towill D. Systems engineering effective supply chain innovations. Int J Prod Res. 2014;52(21):6518-37.

8. Bouncken RB. Supply Chain Contingencies: The Effects of Up-Stream Directives on Supplier's Innovation Performance. Emj-Eng Manag J. 2011;23(4):36-46.

9. Bruce M, Moger ST. Dangerous liaisons: An application of supply chain modelling for studying innovation within the UK clothing industry. Technol Anal Strateg. 1999;11(1):113-25.

10. Buffington J. The Beverage Can in the United States: Achieving a 100\% Recycled Aluminum Can through Supply Chain Innovation. Jom-Us. 2012;64(8):923-32.

11. Buffington J, Peterson R. Defining a Closed-Loop US Aluminum Can Supply Chain Through Technical Design and Supply Chain Innovation. Jom-Us. 2013;65(8):941-50.

12. Chapman RL, Corso M. From continuous improvement to collaborative innovation: the next challenge in supply chain management. Prod Plan Control. 2005;16(4):339-44.

13. Cheng $\mathrm{JH}$, Chen $\mathrm{MC}$, Huang $\mathrm{CM}$. Assessing inter-organizational innovation performance through relational governance and dynamic capabilities in supply chains. Supply Chain Manag. 2014;19(2):173-86.

14. Chiou TY, Chan HK, Lettice F, Chung SH. The influence of greening the suppliers and green innovation on environmental performance and competitive advantage in Taiwan. Transport Res E-Log. 2011;47(6):822-36.

15. Choi TY, Krause DR. The supply base and its complexity: Implications for transaction costs, risks, responsiveness, and innovation. J Oper Manag. 2006;24(5):637-52.

16. Craighead CW, Hult GTM, Ketchen DJ. The effects of innovation-cost strategy, knowledge, and action in the supply chain on firm performance. J Oper Manag. 2009;27(5):405-21.

17. Croom S. Restructuring supply chains through information channel innovation. Int J Oper Prod Man. 2001;21(4):504-15.

18. Davila A, Gupta M, Palmer R. Moving Procurement Systems to the Internet. European Management Journal. 2003;21(1):11-23.

19. de Farias OO, Akabane GK. Innovation and creativity on logistics besides TRIZ methodology. Procedia Engineering. 2011;9:724-9.

20. Dedrick J, Kraemer KL, Linden G. The distribution of value in the mobile phone supply chain. Telecommun Policy. 2011;35(6):505-21. 
21. Detre JD, Johnson AJ, Gray AW. Innovativeness and Innovation: Implications for the Renewable Materials Supply Chain. Int Food Agribus Man. 2011;14(2):17-34.

22. Fawcett SE, Jones SL, Fawcett AM. Supply chain trust: The catalyst for collaborative innovation. Bus Horizons. 2012;55(2):163-78.

23. Ferrer $M$, Santa $R$, Storer $M$, Hyland $P$. Competences and capabilities for innovation in supply chain relationships. Int J Technol Manage. 2011;56(2-4):272-89.

24. Flint DJ, Larsson E, Gammelgaard B. Exploring Processes for Customer Value Insights, Supply Chain Learning and Innovation: An International Study. Journal of Business Logistics. 2008;29(1):257.

25. Flint DJ, Larsson E, Gammelgaard B, Mentzer JT. Logistics Innovation: A Customer Value-Oriented Social Process. Journal of Business Logistics. 2005;26(1):113-47.

26. Gadde L-E. Moving Corporate Boundaries: Consequences for Innovative Redesign. Journal of Supply Chain Management. 2013;49(4):12-26.

27. Gilbert SM, Cvsa V. Strategic commitment to price to stimulate downstream innovation in a supply chain. Eur J Oper Res. 2003;150(3):617-39.

28. Goldsmith PD. Innovation, supply chain control, and the welfare of farmers - The economics of genetically modified seeds. Am Behav Sci. 2001;44(8):1302-26.

29. Gou YZ. Key Factors of Supply Chain Technological Innovations from the Perspective of Logistics Service Providers in China. Marketing Science Innovations and Economic Development. 2010:417-22.

30. Gravier MJ, Swartz SM. The dark side of innovation: Exploring obsolescence and supply chain evolution for sustainment-dominated systems. The Journal of High Technology Management Research. 2009;20(2):87-102.

31. Grawe SJ. Logistics innovation: a literature - based conceptual framework. The International Journal of Logistics Management. 2009;20(3):360-77.

32. Grover D. The 'advancedness' of knowledge in pollution-saving technological change with a qualitative application to SO2 cap and trade. Ecol Econ. 2013;89:123-34.

33. Gualandris J, Kalchschmidt M. Customer pressure and innovativeness: Their role in sustainable supply chain management. Journal of Purchasing and Supply Management. 2014;20(2):92-103.

34. Hall J. Environmental supply chain dynamics. 2000.

35. Harrison T, Waite K. A time-based assessment of the influences, uses and benefits of intermediary website adoption. Inform Manage-Amster. 2006;43(8):1002-13.

36. Hazen BT, Overstreet RE, Cegielski CG. Supply chain innovation diffusion: going beyond adoption. Int J Logist Manag. 2012;23(1):119-34.

37. Helper S, Sako M. Management innovation in supply chain: appreciating Chandler in the twenty-first century. Ind Corp Change. 2010;19(2):399-429.

38. Hobbs JE. Innovation and future direction of supply chain management in the Canadian agri-food industry. Can J Agr Econ. 1998;46(4):525-37.

39. Holmstrom J. Business process innovation in the supply chain a case study of implementing vendor managed inventory. 1998.

40. Hsieh KN, Tidd J. Open versus closed new service development: The influences of project novelty. Technovation. 2012;32(11):600-8.

41. Hurt U, Otto T, Kaare KK, Koppel O. New Approach to Knowledge Transfer Environment Development. Procedia Engineer. 2014;69:273-81. 
42. Iliopoulos C, Theodorakopoulou I, Lazaridis P. Innovation implementation strategies for consumer driven fruit supply chains. Brit Food J. 2012;114(6-7):798-815.

43. Ireland RD, Webb JW. A multi-theoretic perspective on trust and power in strategic supply chains. J Oper Manag. 2007;25(2):482-97.

44. Isaksson R, Johansson P, Fischer K. Detecting Supply Chain Innovation Potential for Sustainable Development. J Bus Ethics. 2010;97(3):425-42.

45. Jabbour CJC, Neto AS, Gobbo JA, Ribeiro MdS, Jabbour ABLdS. "Eco-innovations in more sustainable supply chains for a low-carbon economy: A multiple case study of human critical success factors in Brazilian leading companies". International Journal of Production Economics. 2014.

46. Jaegersberg G, Ure J, Lloyd AD. Trans-regional supply chain research network: Developing innovation strategies within and between regional oil and gas clusters. Complex Systems Concurrent Engineering: Collaboration, Technology Innovation and Sustainability. 2007:801-8.

47. Jensen JK, Govindan K. Assessment of renewable bioenergy application: a case in the food supply chain industry. Journal of Cleaner Production. 2014;66:254-63.

48. Ji GJ. Energy Levels and Co-evolution of Product Innovation in Supply Chain Clusters. Comm Com Inf Sc. 2010;113:140-58.

49. Kim B. Coordinating an innovation in supply chain management. Eur J Oper Res. 2000;123(3):568-84.

50. Kim D, Cavusgil ST, Calantone RJ. Information system innovations and supply chain management: Channel relationships and firm performance. J Acad Market Sci. 2006;34(1):40-54.

51. Kim K-K, Lim MK. R\&D outsourcing in an innovation-driven supply chain. Operations Research Letters. 2015;43(1):20-5.

52. Klassen RD, Vereecke A. Social issues in supply chains: Capabilities link responsibility, risk (opportunity), and performance. International Journal of Production Economics. 2012;140(1):103-15.

53. Lau HCW, Ho GTS, Chan TM, Tsui WT. An innovation approach for achieving cost optimization in supply chain management. J Intell Fuzzy Syst. 2014;26(1):173-92.

54. Lee SM, Lee D, Schniederjans MJ. Supply chain innovation and organizational performance in the healthcare industry. Int J Oper Prod Man. 2011;31(11-12):1193-214.

55. Lee VH, Ooi KB, Chong AYL, Seow C. Creating technological innovation via green supply chain management: An empirical analysis. Expert Syst Appl. 2014;41(16):6983-94.

56. Leung J, Cheung WM, Chu SC. Aligning RFID applications with supply chain strategies. Inform Manage-Amster. 2014;51(2):260-9.

57. Liao SH, Kuo Fl. The study of relationships between the collaboration for supply chain, supply chain capabilities and firm performance: A case of the Taiwan's TFT-LCD industry. International Journal of Production Economics. 2014;156:295-304.

58. Lin HF. The impact of socialization mechanisms and technological innovation capabilities on partnership quality and supply chain integration. Inf Syst E-Bus Manag. 2014;12(2):285-306.

59. Lin YC, Wang $\mathrm{YC}, \mathrm{Yu} \mathrm{CH}$. Investigating the drivers of the innovation in channel integration and supply chain performance: A strategy orientated perspective. International Journal of Production Economics. 2010;127(2):320-32.

60. Matos S, Hall J. Integrating sustainable development in the supply chain: The case of life cycle assessment in oil and gas and agricultural biotechnology. J Oper Manag. 2007;25(6):1083-102. 
61. Michalski M, Yurov KM, Botella JLM. Trust and It Innovation in Asymmetric Environments of the Supply Chain Management Process. J Comput Inform Syst. 2014;54(3):10-24.

62. Modi SB, Mabert VA. Exploring the Relationship between Efficient Supply Chain Management and Firm Innovation: An Archival Search and Analysis. Journal of Supply Chain Management. 2010;46(4):81-94.

63. Morgan K. Organic vs conventional agriculture knowledge power and innovation in the food chain. 2000.

64. Munksgaard KB, Stentoft J, Paulraj A. Value-based supply chain innovation. Oper Manage Res. 2014;7(3-4):50-62.

65. Mylan J, Geels FW, Gee S, McMeekin A, Foster C. Eco-innovation and retailers in milk, beef and bread chains: enriching environmental supply chain management with insights from innovation studies. Journal of Cleaner Production. 2014.

66. Narasimhan R. Perspectives on Supply Network-Enabled Innovations. Journal of Supply Chain Management. 2013;49(4):27-42.

67. Neubert G, Dominguez C, Ageron B. Inter-organisational alignment to enhance information technology (IT) driven services innovation in a supply chain: the case of radio frequency identification (RFID). Int J Comput Integ M. 2011;24(11):1058-73.

68. Nicholas PK, Mandolesi S, Naspetti S, Zanoli R. Innovations in low input and organic dairy supply chains-What is acceptable in Europe? J Dairy Sci. 2014;97(2):1157-67.

69. Oke A, Prajogo DI, Jayaram J. Strengthening the Innovation Chain: The Role of Internal Innovation Climate and Strategic Relationships with Supply Chain Partners. Journal of Supply Chain Management. 2013;49(4):43-58.

70. Palaneeswaran E. Curing congenital construction industry disorders through relationally integrated supply chains. 2003.

71. Panayides PA, So M. Logistics service provider-client relationships. Transport Res E-Log. 2005;41(3):179-200.

72. Panayides PM, Lun YHV. The impact of trust on innovativeness and supply chain performance. International Journal of Production Economics. 2009;122(1):35-46.

73. Paton RA, McLaughlin S. Services innovation: Knowledge transfer and the supply chain. European Management Journal. 2008;26(2):77-83.

74. Peitz M, Shin D. Innovation and waste in supply chain management. J Econ Behav Organ. 2013;86:191-9.

75. Price $H$. The anthropology of the supply chain Fiefs clans witch doctors and professors. 1996.

76. Richey RG, Chen HZ, Genchev SE, Daugherty PJ. Developing effective reverse logistics programs. Ind Market Manag. 2005;34(8):830-40.

77. Roy S, Sivakumar K, Wilkinson IF. Innovation generation in supply chain relationships: A conceptual model and research propositions. J Acad Market Sci. 2004;32(1):61-79.

78. Saad M. A review of the progress towards the adoption of supply chain management SCM relationships in construction. 2002.

79. Saint Jean M. Polluting emissions standards and clean technology trajectories under competitive selection and supply chain pressure. Journal of Cleaner Production. 2008;16:S113-S23.

80. Sampson SE, Spring M. Customer Roles in Service Supply Chains and Opportunities for Innovation. Journal of Supply Chain Management. 2012;48(4):30-50.

81. Schlecht L, Yang M. Impact of prototyping resource environments and timing of awareness of 
constraints on idea generation in product design. Technovation. 2014;34(4):223-31.

82. Seman NAA, Zakuan N, Jusoh A, Arif MSM, Saman MZM. The Relationship of Green Supply Chain Management and Green Innovation Concept. Procedia - Social and Behavioral Sciences. 2012;57:453-7.

83. Shieh CJ. Supply chain management, organizational innovation and corporate culture: The impact of relatedness. Afr J Bus Manage. 2010;4(9):1736-44.

84. Silvestre BS. A hard nut to crack! Implementing supply chain sustainability in an emerging economy. Journal of Cleaner Production. 2014.

85. Singhal J. Supply chains and compatibility among components in product design. 2002.

86. Sobrero M. Strategic management of supplier manufacturer relations in new product development. 2002.

87. Soosay CA, Hyland PW, Ferrer M. Supply chain collaboration: capabilities for continuous innovation. Supply Chain Manag. 2008;13(2):160-9.

88. Tajima M. Strategic value of RFID in supply chain management. Journal of Purchasing and Supply Management. 2007;13(4):261-73.

89. Tan YC, Ndubisi NO. Evaluating supply chain relationship quality, organisational resources, technological innovation and enterprise performance in the palm oil processing sector in Asia. J Bus Ind Mark. 2014;29(6):487-98.

90. Tong X, Shi J, Zhou Y. Greening of supply chain in developing countries: Diffusion of lead (Pb)-free soldering in ICT manufacturers in China. Ecol Econ. 2012;83:174-82.

91. Tseng ML, Chiu SF, Tan RR, Siriban-Manalang AB. Sustainable consumption and production for Asia: sustainability through green design and practice. Journal of Cleaner Production. 2013;40:1-5.

92. Vale M. Innovation and knowledge driven by a focal corporation - The case of the Autoeuropa supply chain. Eur Urban Reg Stud. 2004;11(2):124-40.

93. Verghese $\mathrm{K}$, Lewis $\mathrm{H}$. Environmental innovation in industrial packaging: a supply chain approach. Int J Prod Res. 2007;45(18-19):4381-401.

94. Vijayasarathy LR. An investigation of moderators of the link between technology use in the supply chain and supply chain performance. Inform Manage-Amster. 2010;47(7-8):364-71.

95. Visser R, Jongen M, Zwetsloot G. Business-driven innovations towards more sustainable chemical products. Journal of Cleaner Production. 2008;16:S85-S94.

96. Wagner SM, Bode C. Supplier relationship-specific investments and the role of safeguards for supplier innovation sharing. J Oper Manag. 2014;32(3):65-78.

97. Wang XW, Stosslein M, Wang K. Designing knowledge chain networks in China - A proposal for a risk management system using linguistic decision making. Technol Forecast Soc. 2010;77(6):902-15.

98. Wong CWY, Wong CY, Boon-itt S. The combined effects of internal and external supply chain integration on product innovation. International Journal of Production Economics. 2013;146(2):566-74.

99. Wu GC. The influence of green supply chain integration and environmental uncertainty on green innovation in Taiwan's IT industry. Supply Chain Manag. 2013;18(5):539-52.

100. Wu IL, Chang CH. Using the balanced scorecard in assessing the performance of e-SCM diffusion: A multi-stage perspective. Decis Support Syst. 2012;52(2):474-85.

101. Wu IL, Chuang $\mathrm{CH}$. Analyzing contextual antecedents for the stage-based diffusion of electronic 
supply chain management. Electron Commer R A. 2009;8(6):302-14.

102. Wu IL, Chuang $\mathrm{CH}$. Examining the diffusion of electronic supply chain management with external antecedents and firm performance: A multi-stage analysis. Decis Support Syst. 2010;50(1):103-15.

103. Wulf C, Kaltschmitt M. Life cycle assessment of hydrogen supply chain with special attention on hydrogen refuelling stations. International Journal of Hydrogen Energy. 2012;37(21):16711-21.

104. Wuttke DA, Blome C, Foerstl K, Henke M. Managing the Innovation Adoption of Supply Chain FinanceEmpirical Evidence From Six European Case Studies. Journal of Business Logistics. 2013;34(2):148-66.

105. Yang HM, Choi BS, Park HJ, Suh MS, Chae B. Supply chain management six sigma: a management innovation methodology at the Samsung Group. Supply Chain Manag. 2007;12(2):88-95.

106. Zhang W, Zhang Q, Wu G. Interorganizational Knowledge Division Decision Model Based on Cooperative Innovation of Supply Chain System. Abstr Appl Anal. 2014;2014:1-9.

107. Zhu Q, Sarkis J, Lai K-h. Green supply chain management innovation diffusion and its relationship to organizational improvement: An ecological modernization perspective. J Eng Technol Manage. 2012;29(1):168-85. 


\section{Appendix B: Methodologies applied}

\begin{tabular}{|l|l|}
\hline Methodologies & Reference number of papers \\
\hline \multirow{2}{*}{ Survey } & $\begin{array}{l}5,6,7,8,13,14,16,18,22,23,24,29,30,33,35,42,50,54,55,57,58,59,61, \\
62,69,71,72,76,78,80,83,89,90,94,96,98,99,100,101,102,107\end{array}$ \\
\hline Case Study & $\begin{array}{l}1,9,11,17,20,21,32,34,37,38,39,40,44,45,46,47,48,52,56,60,63,64,65, \\
67,81,84,86,87,92,93,95,103,104,105\end{array}$ \\
\hline Theory & $3,4,10,12,15,19,25,26,28,36,41,43,66,70,73,75,82,85,88,91,97$ \\
\hline Model & $27,31,49,51,53,74,77,79,106$ \\
\hline Review & 2 \\
\hline Other & 68 \\
\hline
\end{tabular}

\section{Appendix C: Countries of Focus}

\begin{tabular}{|c|c|}
\hline Countries of focus & Reference number of papers \\
\hline Australia & $12,7,23,53,69,93,87$ \\
\hline Boland & 42 \\
\hline Brazil & $19,45,60$ \\
\hline Canada & $38,52,84,88,60$ \\
\hline China & $29,48,90,97,106,107$ \\
\hline Demark & 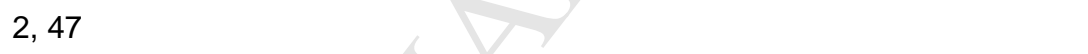 \\
\hline Estonia & 41 \\
\hline France & 67,79 \\
\hline Germany & $6,8,96,103,104$ \\
\hline Greece & 42 \\
\hline Hongkong & $56,70,71$ \\
\hline Italy & 33,86 \\
\hline Malaysia & $55,82,89$ \\
\hline Mexico & 81 \\
\hline Netherlands & $5,95,42$ \\
\hline New Zealand & $26>7$ \\
\hline Nordic Sweden & 39 \\
\hline Porland & 61 \\
\hline Portugal & 92 \\
\hline Singapore & 87 \\
\hline South Korea & $49,54,105$ \\
\hline Spain & $1,42,61$ \\
\hline Sweden & 11,44 \\
\hline Taiwan & $13,40,57,58,59,83,91,99,100,101,102$ \\
\hline Thailand & 98 \\
\hline U.K. & $9,14,17,34,35,37,46,63,65,68,72,73,75,78$ \\
\hline U.S. & $\begin{array}{l}3,4,10,15,16,18,20,21,22,24,25,27,28,30,31,32,36,43,50,51,62 \\
64,66,74,76,77,80,85,94,60\end{array}$ \\
\hline
\end{tabular}


Appendix D: Various Theories applied

\begin{tabular}{|c|c|}
\hline Theories or Models & Reference number of papers \\
\hline Absorptive Capacity & $31,66,84,99$ \\
\hline Ambidexterity Theory & 66,98 \\
\hline Attitude Theory & 101 \\
\hline Balance Score Card (BSC) & 100 \\
\hline Behavioural Theory & $75,100,101,102$ \\
\hline Benchmarking & 7,46 \\
\hline Business Ethics & 44 \\
\hline Chase's Customer Contact Model & 80 \\
\hline Competing Value Framework (CVF) & 66 \\
\hline Competitive Theory & 46,101 \\
\hline Complementarity Theory & $x+2$ \\
\hline Complexity Theory & $-\infty$ \\
\hline Concept of Channel Power & 34 \\
\hline Concept of Core Competencies & 34 \\
\hline Contingency Theory & $40,84,99$ \\
\hline Contractual Coordination Mechanisms & 86 \\
\hline Decision Theory & 97 \\
\hline Demand Distortion & 39 \\
\hline Design Structure Matrix (DSM) & 37 \\
\hline Eco Efficiency Concept & 44 \\
\hline Ecological Modernization Theory (EMT) & 107 \\
\hline Evolution Theory & $63,65,84$ \\
\hline Exploitation-Exploration Theory & 31,88 \\
\hline Fitness Landscapes Theory & 60 \\
\hline Fuzzy Theory & 70,97 \\
\hline Game Theory & $23,30,97$ \\
\hline Industrial Marketing And Purchasing (IMP) Theory & 77 \\
\hline Innovation Diffusion Theory & $35,61,100,101,102,104,107$ \\
\hline Innovation Dynamics & 60 \\
\hline Institutional Theory & 13,48 \\
\hline Interaction Theory & 77 \\
\hline Inventory Echelon & 57 \\
\hline Lead Market Theory & 90 \\
\hline Life Cycle Management & $45,60,93,103$ \\
\hline Linguistic Decision Making Model (LDMM) & 97 \\
\hline Mindfulness Theory & 56 \\
\hline Neoclassic Economics & 28 \\
\hline Network Theory & $3,3,12,31,77$ \\
\hline NK Model & 15 \\
\hline Optimal Control Theory & 49 \\
\hline
\end{tabular}




\begin{tabular}{|l|l|}
\hline Organization Theory & $5,20,34,60,72,86,88$ \\
\hline Profiting from Innovation (PFI) & 20 \\
\hline Property Right Theory & 26 \\
\hline Quality Management & 44 \\
\hline Quantum Energy Level Theory & 48 \\
\hline Relationship Theory & $4,6,22,70,77,96$ \\
\hline Resource-Based Theory & $3,3,5,13,16,16,22,23,26,31,31,31,43$, \\
\hline Risk Management & $50,58,59,61,69,69,84,89,91,99$ \\
\hline Schumpeterian Innovation Framework & 60 \\
\hline Service Theory & 31 \\
\hline Six Sigma & 80 \\
\hline Social Theory & 105 \\
\hline Stakeholder Theory & $3,43,58,65,69,72,97$ \\
\hline Strategic Approach & $33,44,52,60,84$ \\
\hline Structural Density Theory & $16,67,67,86,92$ \\
\hline Systems Theory & 3 \\
\hline TCOS Uncertainties & $15,34,44,65,92$ \\
\hline Technology Acceptance Model (TAM) & 84 \\
\hline Theory of First-Mover Advantages & $100,101,102$ \\
\hline Theory of S-Curves & 88 \\
\hline Theory of Swift And Even Flow & 31 \\
\hline Transaction Cost Theory & 62 \\
\hline Triple Bottom Line & $4,6,12,17,26,28,34,38,43,61,86,96$ \\
\hline TRIZ & 52,91 \\
\hline Unified Theory of Acceptance And Use of Technology & 19 \\
\hline (UTAUT) & 36 \\
\hline Virtual Enterprise (VE) & 100,102 \\
\hline
\end{tabular}


From a systematic literature review to integrated definition for Sustainable Supply

\section{Chain Innovation (SSCI)}

- First systematic literature review of sustainable innovation in supply chain

- Refine definition for supply chain innovation (SCI)

- Develop definition for sustainable supply chain innovation (SSCI)

- Identify characteristics of sustainable supply chain innovation (SSCI)

- Propose a set of opportunities for future research 